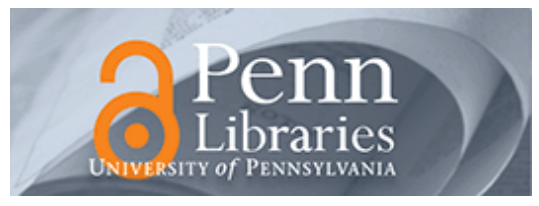

University of Pennsylvania

ScholarlyCommons

Real Estate Papers

Wharton Faculty Research

3-2007

\title{
Immigration and Housing Rents in American Cities
}

Albert Saiz

Follow this and additional works at: https://repository.upenn.edu/real-estate_papers

Part of the Economics Commons, and the Real Estate Commons

\section{Recommended Citation}

Saiz, A. (2007). Immigration and Housing Rents in American Cities. Journal of Urban Economics, 61 (2), 345-371. http://dx.doi.org/10.1016/j.jue.2006.07.004

This paper is posted at ScholarlyCommons. https://repository.upenn.edu/real-estate_papers/69

For more information, please contact repository@pobox.upenn.edu. 


\title{
Immigration and Housing Rents in American Cities
}

\author{
Abstract \\ Is there a local economic impact of immigration? Immigration pushes up rents and housing values in US \\ destination cities. The positive association of rent growth and immigrant inflows is pervasive in time \\ series for all metropolitan areas. I use instrumental variables based on a "shift-share" of national levels of \\ immigration into metropolitan areas. An immigration inflow equal to $1 \%$ of a city's population is \\ associated with increases in average rents and housing values of about $1 \%$. The results suggest an \\ economic impact that is an order of magnitude bigger than that found in labor markets. \\ Keywords \\ immigration, housing prices \\ Disciplines \\ Business | Economics | Real Estate
}




\title{
WORKING PAPER NO. 03-12 IMMIGRATION AND HOUSING RENTS IN AMERICAN CITIES
}

\author{
Albert Saiz \\ Federal Reserve Bank of Philadelphia
}

June 2003

\begin{abstract}
This paper is a revised version of chapter 2 of my dissertation at Harvard University and does not necessarily represent the views of the Federal Reserve Bank of Philadelphia or the Federal Reserve System. Thanks to David Cutler and Ed Glaeser for guidance. Thanks to seminar participants at U.C. Irvine, ESPE 2003 meetings, the Federal Reserve Banks of New York and Philadelphia, George Washington University, Harvard, HEC-Montreal, NBER Summer Institute, Universitat Pompeu Fabra, University of Toronto (Rotman School), The Wharton School, and York University for comments. Special thanks are due to Pablo Casas-Arce and Tara Watson for detailed comments on an earlier version of the paper. None of the above could avoid the shortcomings in this version of the paper, which are only attributable to the author. I gratefully acknowledge financial support from the Harvard Program in Inequality and Social Policy and the Lincoln Institute for Land Policy.
\end{abstract}




\title{
IMMIGRATION AND HOUSING RENTS IN AMERICAN CITIES
}

\begin{abstract}
Is there a local economic impact of immigration? Immigration pushes up rents and housing values in destination cities. The positive association of rent growth and immigrant inflows is pervasive in time series for all metropolitan areas. I use instrumental variables based on a "shift-share" of national levels of immigration into metropolitan areas. Conditioning on other variables, an immigration inflow equal to $1 \%$ of the city population is associated with increases in rents and housing values of about $1 \%$. The results suggest an economic impact that is an order of magnitude bigger than that found on labor markets.
\end{abstract}

Keywords: Immigration, housing rents

JEL: J61, R23, R31 


\section{Introduction}

Immigration continues to be one of the most important factors in the demographic evolution of the United States. Immigrants and their offspring will account for as much as two thirds of population growth from 1995 to $2050 .{ }^{1}$ And its effects will be particularly salient in the areas where immigrants cluster. In 2000, 68 percent of all foreign-born persons (as opposed to 36 percent of the native population) lived in only six states: California, New York, Florida, Texas, New Jersey or Illinois. ${ }^{2}$ Major American metropolitan areas, such as New York, Los Angeles, Miami and San Francisco, have seen levels of new legal immigration equal to more than $13 \%$ of their initial population in only fifteen years (1983-1997). ${ }^{3}$ What is the local impact of such immigration inflows in American cities? To answer this question, economists have focused on wage impacts and have found only small effects. ${ }^{4}$ In this paper I argue for the importance of the housing market and find an impact on the purchasing power of renters that is an order of magnitude bigger than the estimates from the wage literature. The results are very important in understanding the local distributive impact of immigration and the link between immigration and the residential location decisions of natives.

Housing markets can no longer be ignored when studying the local economic impact of immigration. Immigrants will represent a sort of new "baby boom" for the American housing markets of the $21^{\text {st }}$ century. Already, from 1980 to 1998, foreign-born renter households increased their share of total renter-occupied housing from $15 \%$ to $28 \%$ in the Northeastern and Western states. Immigrant households accounted for a third of total household growth during the 1995-2000 period (JCHS, 2000, 2001). And immigration determines housing demand to an even greater extent in those metropolitan areas where the foreign born tend to settle.

\footnotetext{
1 The National Research Council study (NRC, 1997) provides a comprehensive review of the demographic importance of immigration in the United States.

${ }^{2}$ See Passel and Zimmerman (2001).

${ }^{3}$ In Table A.1 I show these major "immigrant cities."

${ }^{4}$ Studies on wage impacts represent the bulk of the research on immigration in economics. However, it is only fair to acknowledge studies on fiscal impacts (e.g. Borjas and Hilton, 1996), natural resources (Simon, 1999, Chapter 9), college admissions for minorities (Hoxby, 1998), native self-employment (Fairlie and Meyer, 2000), unemployment (Gross, 1999; Gang and Rivera-Batiz, 1999) and the impact of foreign teaching fellows, like this author, on the academic performance of US undergraduates (Borjas, 2000).
} 
This paper uses annual data on legal immigration inflows and decennial data on the stock of the foreign-born, housing rents, and home values at the metropolitan area level. The evidence suggests that part of the distributive impact of immigration on local economies may come through changes in rents and housing prices. I use longitudinal and cross-sectional data and find that cities with major inflows of immigrants experienced higher rent growth during the period 1983-1997. Legal immigration inflows equal to 1\% of a city's population were associated with increases in housing rents and prices of about $1 \%$. I include state fixed effects to account for different regional trends that could be spuriously correlated with the immigrants' geographic patterns of settlement. I further use annual differences in immigration inflows by city, and find that rents accelerate when immigration inflows into a metropolitan area accelerate. To avoid the possible endogeneity of immigration with respect to other omitted factors that generate rent growth I use instruments based on general changes in the national levels of immigration, on changes in the characteristics of the countries that send immigrants, and on the distribution of immigrants in earlier periods. The association between immigration and rent growth is not driven by local contemporaneous shocks that could be correlated with immigration. Thus the results support a causal interpretation. I find similar results using long differences in rents and housing prices and the cumulative number of legal immigrants by metropolitan area during the 1983-1997 period, which do not hinge on the timing of immigrant admissions. I also use data from the American Housing Survey to control for unit-specific characteristics that could account for the rent results via composition effects. The results are very robust to this alternative data set. Finally, to allay any concerns about the omission of illegal immigrants, and to provide further alternative data sources for rents and housing prices, I use data from the 1970, 1980, 1990 and 2000 US censuses. OLS regressions, instrumental variables that use immigration levels to predict subsequent inflows, and MSA fixed effects regressions that are identified by using within-city variation in the immigration inflows between censuses yield similar results.

The findings in this paper contrast sharply with the results from the labor literature on immigration (Borjas, 1994a; Friedberg and Hunt, 1995). Studies that use historical data find a negative local association between immigration and wages in periods previous to WWI (Goldin, 1994; Ferrie, 1996a). But remarkably, there is not much evidence of such a relationship holding in the contemporaneous metropolitan US. ${ }^{5}$ Even unexpected immigration

\footnotetext{
${ }^{5}$ Structural models of the economy that use realistic parameters to calibrate a simple model of labor demand predict an impact of immigration on wages at the national level (Borjas, Freeman and Katz, 1992).
} 
shocks that rapidly expand the local labor supply do not seem to decrease wages (Card, 1990). There have been so far at least three possible explanations for this surprising result. Natives may be choosing to leave when immigrants arrive, rather than face increased competition in the labor market (Filer, 1992); immigrants may be moving into cities with positive shocks in productivity and wage growth; or the local labor demand may be more elastic than economists have thought (Card and Krueger, 1995). The evidence in this work supplies the literature with a new piece in the puzzle of the local impact of immigration. It shows a potential way in which immigrants can have a local distributive impact. Furthermore, it suggests another major mechanism by which immigration can affect the migration decisions of natives. Rents and housing prices should not be neglected when thinking about the "dynamic process through which natives respond to these supply shocks and reestablish labor market equilibrium" (Borjas, 1994a).

The rest of the paper is organized as follows. Section 2 describes some stylized facts about the housing conditions of immigrants. It also describes the scant previous research about the impact of immigration on housing markets, and the empirical challenges of such an exercise. Section 3 reviews some ideas that are relevant to the economics of immigration and housing prices. I lay out a simple model that studies the response of the housing market in the short run and the long run. The model also contemplates mobility by natives and the interplay between labor and housing markets. Section 4 describes the data sources. Section 5 introduces the methodology and results of the paper. Section 6 concludes.

\section{The empirics of immigration and housing}

Few papers have addressed the topic of immigration and the housing market. A number of studies describe the housing condition of immigrants. We know that immigrants tend to live in rental housing (JCHS, 2000, Burnley, Murphy and Fagan, 1997) and in housing units of lower quality, especially during the period just after they arrive (Thave, 1999; Friedman, Rosenbamum and Schill, 1998). We also know that immigrants tend to consume less with respect to housing services: crowding is more frequent in immigrants' households (Myers, Baer and Choi, 1996). ${ }^{6}$ Over time, immigrants tend to resemble natives more in terms of crowding, home ownership and suburbanization patterns (Callis, 1997; Myers, 1999; Myers and Lee, 1996, Myers and Park, 1999).

\footnotetext{
${ }^{6}$ The demographic literature on crowding defines it as when a housing unit holds more than one person per room (not including kitchens, baths and the like).
} 
Much less is known about the impact of immigrants in destination cities. Muller and Espenhade (1985) report that rental housing experienced major price increases in Los Angeles, compared to other American metropolitan areas, during the period 1967-83. Los Angeles was one of the most important "gateway" cities for immigration in that period. The authors go on to explain this finding: "because most immigrants live in rental units, the rental housing market would experience substantial pressure from the rising immigrant-induced demand." The evidence points to housing markets as a possible way to find the local effects of immigration.

Burnley, Murphy and Fagan (1997) report that immigration is one of the important correlates of short and long-term inflation of housing prices in Sidney, the main immigrant city in Australia. Ley and Tuchener (1999) find a similar time-series correlation between housing prices and immigration in Toronto and Vancouver, Canada. These studies are descriptive in nature. The authors do not control for other variables that could account for changes in housing prices, such as economic cycles.

Research in this area presents several challenges. Firstly, omitted variables that are not observed by the researcher could be driving both immigration inflows and housing costs. Immigrants may respond to other factors that cause rents to increase, such as expectations of future economic growth, improved amenities or changes in the preferences for existing amenities. In principle, this could lead the researcher to overestimate the impact of immigration on rents. Note, however, that this could be less of a concern for the impact of immigration on housing values, since capitalization of forecastable future amenities should have occurred ex ante. ${ }^{7}$ Secondly, immigration could be endogenous. Immigrants may be looking for better deals: they might decide to settle in places where rents are increasing more slowly. If immigration inflows are very sensitive to housing costs then the estimates of the relation between immigration and rents could be biased downward. In this context, we need to look for exogenous sources of variation in the immigration inflows to ascertain causality.

Saiz (2003) provides evidence of a causal relationship between immigration inflows and housing rents. I used the "Mariel Boatlift" 8 as a natural experiment, following Card's

\footnotetext{
${ }^{7}$ This latter argument hinges on the efficiency of the housing market.

${ }^{8}$ About 150,000 Cuban refugees arrived in the United States between May and September 1980. They had been allowed to flee from Cuba after political turmoil in the island. A short-lived decision by the Castro government granted them a permit to leave. Many of these immigrants (some estimated 80,000) decided to
} 
(1990) study about labor market outcomes. This immigration shock represented an exogenous increase of $9 \%$ in the Miami renter population in one year (or about $4 \%$ of the total population). I showed that rents increased $8 \%$ more in the Miami metropolitan area than in the rest of metropolitan Florida and two other groups of comparison cities. Immigration was the most likely explanation for this differential growth in rents; but the differences-in-differences approach that Saiz (2003) uses has shortcomings that are worth mentioning. Different trends in the "treatment" and "control" groups can generate spurious results. ${ }^{9}$ This criticism does not claim there is a systematic bias in the diffs-indiffs estimates, but suggests a potential lack of power of the methodology. A second shortcoming of the differences-in-differences approach is that, even if the econometrician can establish causality, the estimates need not be generalizable. Saiz (2003) measures the impact of a very big unexpected immigration shock on a very particular housing market, at a specific point in time.

\section{The economics of immigration and rents}

Why should we be specifically interested in the impact of immigration on rents? How is immigration different from general population growth? Is it surprising to find a substantial impact of immigration on local housing markets? From a housing market perspective, several facts distinguish immigration from general population growth.

Immigrants are much more spatially concentrated than natives. This is the housing market equivalent of the difference in the skill composition of the immigrant and native populations in the labor market (Borjas, 1994b). Consider the 20 major metropolitan areas by the levels of new legal immigration in the period 1983-1997 (Table A.1). Two thirds of all metropolitan immigrants (immigrants in metropolitan areas) moved into metropolitan areas that represented only one third of the United States' metropolitan population. More than half of the new immigrants settled in only ten Metropolitan Statistical Areas (MSA), which contained just $20 \%$ of the metropolitan population. About $20 \%$ of Americans lived in non-metropolitan areas in 1980. Only $4.34 \%$ of immigrants admitted during the 1983-97 period reported settling

settle in Miami because of the proximity of Southern Florida to Cuba and the fact that a major Cuban émigré community was already present there.

${ }^{9}$ Other factors may have been at play in Miami during the early 80 s. These factors may have affected rents differently in that metropolitan area. Angrist and Krueger (2000) show how another failed "Mariel boatlift" in 1994 -thousand of Cubans took to the sea that year but were prevented from landing in Miami by the US Navy- could have been interpreted as having a negative effect on wages using a diffs-in-diffs methodology. 
outside metropolitan areas. We can thus expect the effect of immigration to be stronger on specific housing markets. The factors attracting immigrants to "immigrant cities" are different from the factors motivating natives to migrate. Immigrants are attracted to cities with strong immigrant and ethnic networks. Natives are, by and large, indifferent to these networks. Some of the factors that explain migration by natives are employment, wages, amenities and, critically, housing prices - they tend to look for less expensive locations. Thus it would not be surprising to find a mild correlation between changes in housing prices and changes in native population. Immigration inflows may be more independent from changes in housing supply factors that explain rent growth.

Yet it is not obvious that we should actually see a local correlation between immigration and housing rents. Consider one of the arguments in the labor literature. Natives may move out or avoid areas where immigrants settle because of the competition in the local labor market. If immigrants substituted for natives "one for one" in the labor market, then we would not see any increase in the local demand for housing. Finding a positive local effect of immigration on rents allows us to reject the strong null of "complete displacement" in the labor market.

A similar argument applies to competition in the housing market. Immigrants may be less sensitive to housing rents, because local immigrant-specific amenities and networks are more important for them. Natives, though, may be more sensitive to local rents. If this is the case, immigration inflows could spur net out-migration of natives because of the increased housing costs that are associated with a housing demand shock. There is no way to separate the effect of increased housing demand (immigration) from the potential decreased demand (native outmigration). Part of the local response to the treatment (immigration) can occur through native out-migration. In this case, we need to be careful about the interpretation of the coefficient of immigration on rents. In general it will not correspond to the housing supply elasticity. Nevertheless, we should expect a positive effect of immigration on rents if natives are not infinitely sensitive to changes in housing costs, and if they are not displaced "one for one" in the labor market.

I introduce a simple model that incorporates all these ideas. This model can be used as a roadmap to understand the local impact of immigration on housing. It is structured around the idea of spatial equilibrium with simple supply and demand schedules. The focus is on partial equilibrium: I concentrate on the effects of immigration on a city, which I will name city C. The model contemplates housing supply and the mobility of natives. 
Start by assuming that the preferences of native residents can be represented by the following separable utility function:

$$
U_{i C}=V_{i C}+\alpha \frac{h^{(1-\theta)}-1}{(1-\theta)}+w_{C}(N)-R \cdot h
$$

$V_{i C}$ is the value of local amenities in city $C$ for individual $i, h$ is the consumption of housing services by the individual. $w_{C}$ is the going wage in city $C$; all city dwellers are assumed to be also workers and $w_{C}$ to be a function of the population $(N)$. $R$ stands for housing rents (the annual cost of a dwelling). The model abstracts from income effects in housing consumption. The optimal consumption of housing in this setup is given by $h=\left(\frac{\alpha}{R}\right)^{1 / \theta}$.

The preferences for the city's amenities are distributed uniformly. We can order individuals according to their preferences for the city's amenities: $\{0, \ldots, i\}$. Assume that the preferences for each individual can be represented thus: $V_{i C}=A-a \cdot i$. I also use a linear approximation for the demand of labor: $w_{C}=\overline{w_{C}}-\rho \cdot\left(N_{C}+N_{I}\right) . N_{C}$ is the number of native residents and $N_{I}$ is the foreign-born population in $C$

The utility level outside the city is $\bar{u}$. Residents in the city prefer staying to emigrating, so $U_{i C} \geq \bar{u}, \forall i \in C$. The marginal native will be indifferent between staying at $C$ and leaving.

$$
A-a \cdot N_{C}+\frac{\theta}{1-\theta} \cdot \alpha^{\frac{1}{\theta}} \cdot R^{\frac{\theta-1}{\theta}}-\frac{\alpha}{1-\theta}+\overline{w_{c}}-\rho \cdot\left(N_{C}+N_{I}\right)=\bar{U}
$$

From this equation we derive the supply of natives in $C$ :

$$
N_{C}=\frac{1}{(a+\rho)} \cdot\left\{\Omega-\rho N_{I}+\frac{\theta}{1-\theta} \cdot \alpha^{\frac{1}{\theta}} \cdot R^{\frac{\theta-1}{\theta}}\right\}
$$

, where $\Omega=\left[A+\bar{w}-\bar{U}-\frac{\alpha}{1-\theta}\right]$.

Immigrants are attracted to particular cities because of the existence of previous immigrant communities. Local public goods (such as social networks, schools, language usage, and existence of restaurants and specialized shops) increase the amenity value of such cities from their point of view. The existence of such immigrant-specific amenities in some cities is a well- 
established fact in the literature. ${ }^{10}$ Table A.2 illustrates this point. It shows the correlation between changes in non-immigrant population, total legal immigration and several other variables between 1983 and 1998. Immigration to an MSA is very strongly and positively correlated with the previous density of the foreign born population (with a remarkable correlation coefficient of 0.89 ). Other population growth is only weakly correlated with the immigrant stock. This clearly points to the existence of differential amenities for the native and foreign-born population.

I model this amenity differential by assuming the following amenity value for all immigrants at city C: $V_{i C}=A_{I C}$, where $A_{I C} \geq A$ is an amenity premium for immigrants in "immigrant cities." For the purposes of this work, the only distinction between immigrants and natives is a preference for specific "immigrant" cities. Immigrants will always prefer C. I treat the supply of immigration into city $\mathrm{C}$ as exogenous to the initial spatial equilibrium. My empirical specifications try to make this assumption as accurate as possible.

The optimal consumption of housing services for immigrants will be identical to the consumption of natives. Let total population $N=N_{C}+N_{I}$. The total demand for housing services is equal to the number of residents times the consumption per resident $(N \cdot h)$. Taking logarithms of this identity:

$$
\ln H^{D}=\ln \left(N_{C}+N_{I}\right)+\frac{1}{\theta} \cdot \ln \alpha-\frac{1}{\theta} \cdot \ln R
$$

Let's first analyze the effects of an unexpected immigration shock in the short run. I define the short run as the situation in which supply of housing space and native population cannot change (because of arbitrarily high adjustment costs in the short run). Differentiating equation (4) with respect to the number of immigrants, we obtain the short run impact of unexpected immigration:

$$
\left.\frac{d R}{d N_{I}}\right|_{H=\bar{H}, N_{C}=\overline{N_{C}}}=\theta \cdot \frac{R}{N}
$$

\footnotetext{
${ }^{10}$ Edin, Fredriksson and Åslund (2003), and Munshi (2003) provide convincing evidence on the importance of ethnic enclaves and local immigrant networks. Some examples of the sociological literature on the topic include NRC (1997,) Portes and Rumbaut, (1996), Rumbaut (1997). Zhou (1998) reports that "over two thirds of the legal immigrants admitted to the United States since the 1970s are family-sponsored immigrants. Even among employer-sponsored migrants, the role of networking is crucial. Family, kin, and friendship networks also tend to expand exponentially serving as a conduit to additional and thus potentially self-perpetuating migration."
} 
So the percentage change in rents depends on the "immigration impact" (number of immigrants over population) and the elasticity of the demand for space. All of the adjustment in the short run comes through changes in the demand for space of residents. ${ }^{11}$

For expected immigration shocks, or for learning about the dynamic effects of unexpected shocks, we have to consider both the adjustment of the housing supply, the response of native population, and changes in housing space consumption.

The price elasticity of housing supply is assumed constant:

$$
\ln H^{S}=\beta_{0}+\beta_{1} \ln P
$$

It is well known that changes in housing prices exhibit a high degree of auto-correlation (Case and Shiller, 1999). Contrary to what happens in other asset markets, contemporary changes in prices have predictive power over future price changes. Prices do not fully adjust instantaneously despite the fact that the agents can estimate the steady state price. In order to illustrate the dynamics of housing prices I follow recent papers in the real estate literature, ${ }^{12}$ which postulates an error correction process with respect to the steady state price $\left(P^{*}\right)$.

$$
\frac{\partial P}{d t}=\lambda \cdot\left(P^{*}-P\right)
$$

The steady state housing price capitalizes the steady state housing rent at interest rate $i^{13}$

$$
P^{*}=\frac{R^{*}}{i}, \quad \text { or } \quad \ln P^{*}=\ln R^{*}-\ln i
$$

What is the steady state impact of an immigration shock on housing rents? Housing demand (4) equals housing supply (6) in the steady state (I henceforth drop the stars in the steady state variables for ease of exposition). Combining the equilibrium condition with (8) we obtain:

$$
\ln R=\frac{1}{\left(\beta_{1}+\frac{1}{\theta}\right)}\left\{\ln \left(N_{C}+N_{I}\right)+\frac{1}{\theta} \cdot \ln \alpha-\beta_{0}+\beta_{1} \cdot \ln i\right\}
$$

\footnotetext{
11 This effect can be interpreted as reduction in vacancy rates, increased crowding or conversion of other spaces to residential usage.

12 Meese and Wallace (1997), Malpezzi (1999), Capozza, Hendershott, Mack, and Mayer (2002).

$13 i$ can be interpreted here more generally as the user cost of residential capital.
} 
Differentiating with respect to $N_{I}$ :

$$
\frac{1}{R} \cdot \frac{d R}{d N_{I}}=\frac{1}{\left(\beta_{1}+\frac{1}{\theta}\right)} \cdot \frac{1}{N} \cdot\left(1+\frac{\partial N_{C}}{\partial R} \cdot \frac{\partial R}{\partial N_{I}}+\frac{\partial N_{C}}{\partial w} \cdot \frac{\partial w}{\partial N_{I}}\right)
$$

From equation (2), which defines $N_{C}=N_{C}\left(R\left(N_{I}\right), w\left(N_{I}\right)\right)$ we know that:

$$
\begin{gathered}
\frac{\partial N_{C}}{\partial R}=-\left(\frac{\alpha^{\frac{1}{\theta}}}{R^{\frac{1}{\theta}} \cdot(a+\rho)}\right) \\
\frac{\partial N_{C}}{\partial w} \cdot \frac{\partial w}{\partial N_{I}}=-\frac{\rho}{(a+\rho)}
\end{gathered}
$$

Substituting in (10) and rearranging yields:

$$
\frac{d R}{d N_{I}}=\frac{a \cdot R^{\frac{1}{\theta}}}{\left(\beta_{1}+\frac{1}{\theta}\right) \cdot N \cdot(a+\rho) \cdot R^{\frac{1-\theta}{\theta}}+\alpha^{\frac{1}{\theta}}}
$$

The impact of expected immigration inflows (or the long run effect of unexpected shocks) is smaller than the short run impact of unexpected shocks. New supply of housing, changes in the consumption of space, and out-migration of natives account for this result. At the same time, even in the long run, immigration is expected to have an impact on rents and prices in receiving cities as long as there are natives with a positive consumer surplus derived from living in city C. It is straightforward to show that:

$$
\frac{\partial \frac{d R}{d N_{I}}}{\partial \beta_{1}}<0, \frac{\partial \frac{d R}{d N_{I}}}{\partial \rho}<0, \frac{\partial \frac{d R}{d N_{I}}}{\partial a}>0, \text { and } \frac{\partial \frac{d R}{d N_{I}}}{\partial \theta}>0{ }^{14}
$$

Thus the impact of immigration on rents is lower in cities with elastic housing supply or, less intuitively, in cities with inelastic labor demand, and higher in cities with low price elasticity of housing demand or inelastic supply of natives (i.e. low mobility).

Although not central for the empirical exercise in this paper, it is interesting to discuss some aspects of the interaction between labor markets and the housing impact of immigration.

\footnotetext{
${ }^{14}$ For the later result, I assume that the initial consumption of space is greater than 1 unit $(\mathrm{h}>1)$.
} 
Concretely, consider the strong null hypothesis that natives are displaced one by one from the city because of competition in the labor market. This would certainly explain the apparent lack of a wage impact of immigration in cross-sectional studies. Formally this can be expressed as $\frac{\partial N_{C}}{\partial w} \cdot \frac{\partial w}{\partial N_{I}}=-\frac{\rho}{(a+\rho)}=-1$. For this condition to hold, it is necessary that either $a=0$ (i.e. natives are extremely mobile and sensitive to changes in consumption), or $\rho \rightarrow \infty$ (totally inelastic labor demand). Both of these cases imply, in equation (13) that $\frac{d R}{d N_{I}}=0$. Thus, finding a local impact of immigration on rents helps us to discard the strong null hypothesis of complete displacement in local labor markets.

But then again, wouldn't it be enough to look at population (or employment) net inflows to ascertain if immigration has a local economic impact? The answer to that question is no. Think about a city with a very inelastic housing supply. Assume that the demand for space is relatively inelastic, maybe because of indivisibilities in the existing housing stock. Under this scenario most of the impact of immigration is on housing rents, as opposed to population. As the size of the labor force does not change much, the wage impact of immigration is bound to be small. An outside observer of this scenario may conclude that competition in the labor market drives natives out of the city: i.e. labor demand is inelastic or the supply of natives is very elastic. In fact, neither of these two needs to be true. New immigrants are simply willing to bid up for locations at immigrant cities.

What are the dynamics of rents and prices after an immigration shock? From equation (7) we obtain:

$$
P(t)=P^{*}-\left(P^{*}-P(0)\right) \cdot e^{-\lambda t}
$$

Where $P^{*}$ is the steady state price after the immigration shock and $P(0)$ is the initial steady state price. From (8) it follows that in the steady state comparative statics $\frac{\partial P}{\partial N_{I}} \cdot \frac{1}{P}=\frac{\partial R}{\partial N_{I}} \cdot \frac{1}{R}$, and thus from $(15)$ that $\left(P^{*}-P(0)\right)>0$. The housing market is in equilibrium at any point in time:

$$
\beta_{0}+\beta_{1} \cdot \ln P(t)=\ln \left(N_{C}(t)+N_{I}^{\text {final }}\right)+\frac{1}{\theta} \cdot \ln \alpha-\frac{1}{\theta} \cdot \ln R(t)
$$

The supply of natives is a function of rents at time t and using (3): 


$$
\begin{aligned}
& \beta_{0}+\beta_{1} \cdot \ln \left\{P^{*}-\left(P^{*}-P(0)\right) \cdot e^{-\lambda t}\right\}= \\
& \ln \left(\frac{1}{(a+\rho)} \cdot\left\{\Omega-\rho N_{I}+\frac{\theta}{1-\theta} \cdot \alpha^{\frac{1}{\theta}} \cdot R(t)^{\frac{\theta-1}{\theta}}\right\}+N_{I}^{\text {final }}\right)+\frac{1}{\theta} \cdot \ln \alpha-\frac{1}{\theta} \cdot \ln R(t)
\end{aligned}
$$

Differentiating with respect to time and rearranging we can show:

$$
\frac{\partial R(t)}{\partial t}=-\frac{\beta_{1}}{\left(\frac{\alpha^{\frac{1}{\theta}} \cdot R(t)^{-\frac{1}{\theta}}}{(a+\rho) \cdot N(t)}+\frac{1}{\theta R(t)}\right)} \cdot \frac{\lambda \cdot\left(P^{*}-P(0)\right) \cdot e^{-\lambda t}}{H(t)}<0
$$

In the model, rents experience a shock after the immigration inflow and decrease thereafter toward the new steady state, which is higher than the initial one. Thus one has to be careful separating the short run and long run impacts of immigration on rents. Concretely, identification techniques based on unexpected major shocks, as in Saiz (2003), will tend to overestimate the long run impact of immigration, while identifying its short run effects.

Furthermore, note that general population growth need not be associated with increasing rents. The native population is attracted by areas with low housing costs and is thus endogenous to the rent level. Positive shifts in the housing supply that cause reductions in $\beta_{0}$ in the model are associated with bigger populations and smaller housing rents. The correlation between native population growth and changes in rents needn't be identical to the correlation between exogenous immigration inflows and rent growth.

\section{Data}

In order to assess the impact of immigration inflows on housing markets I have assembled data on rents, housing prices, immigration, income, employment and other characteristics of the US metropolitan areas during the periods 1983-1997, and decennial data for 1970-2000. In this section I describe and summarize the data that I use in the empirical part. A more detailed explanation of how variables are constructed can be found in the data Appendix.

One data source for the immigration inflows is the Immigration and Naturalization Service (INS) "Immigrants Admitted to the United States" series. The main variables for this work are the nationality of the immigrant and the zip code of intended residence. I construct yearly immigration inflows by metropolitan area from 1983 to 1997 matching zip codes to 1993 
metropolitan statistical areas using the census MABLE geo-correlation engine. ${ }^{15}$ It is remarkable that the datasets contain annual individual information on all legal immigrants admitted in the United States. However, the data have several caveats that make it less than optimal. The timing of the admission of a foreign person as an immigrant needn't coincide with the date of entry into the US. Also, the data do not yield any information on illegal immigrants.

But there are several advantages that make the data attractive. First, most immigrants are admitted shortly after they arrive in the US. In 1990, the median year in my sample, 70 percent of admitted immigrants entered the country the same year in which they were admitted. About 90 percent of the immigrants admitted in 1990 report having arrived in the United States in or after 1988. Moreover, admission as an immigrant is by itself a treatment of considerable interest, since the counterfactual may imply having to leave the country or lacking the ability to work, and since it can be useful to forecast the impact of future immigration inflows with the data that is available annually. Thus I will treat these data as a noisy indicator of recent immigration inflows, and obtain a panel with about 292 MSAs and 15 years' worth of data. The measurement error will typically lead us to underestimate the impact of immigration when using higher frequencies. ${ }^{16}$ Second, the data give us information about the nationality of all recent immigrants and I can link this with changes in economic and social conditions in their origin countries. Third the data provide information on the original destination of the immigrant so that the treatment is plausibly more exogenous to the subsequent evolution of rents in the metropolitan area.

An alternative data source for the number of immigrants by city is provided by the census. Concretely, I use the change in the decennial number of foreign-born individuals by MSA. The benefits of using the census tabulations are that they enumerate both legal and illegal immigrants (and other inflows of foreign-born individuals) and that they provide a relatively accurate head-count of the number of immigrants by metropolitan area. The costs of using the census tabulations are the reduction in the periodicity (only each ten years), the loss of some micro information, ${ }^{17}$ and the fact that, between censuses, immigrants may decide to resettle to

\footnotetext{
${ }^{15}$ I calculate immigration inflows using calendar years rather than fiscal year (both are present in the data).

${ }^{16}$ Note that the instrumental variables approaches will also help us deal with attenuation bias.

${ }^{17}$ Census micro data samples do not allow to identify all metropolitan areas. Moreover, there is no detailed information on year of arrival in the present metropolitan area.
} 
locations that are becoming relatively cheaper. In any case, it is remarkable that the results from using both types of immigration data are very similar.

A data source for rents in MSAs is the Department of Housing and Urban Development's (HUD) Fair Market Rent series (FMR). Fair market rents for a fiscal year are determined before October of the previous calendar year. ${ }^{18} \mathrm{I}$ use the year in which FMR are calculated to define my rent variable. I then match these yearly data on rents to the immigration data for the period 1983-1997. The FMR corresponds to the price of a vacant 2-bedroom rental unit at the $45^{\text {th }}$ percentile of the MSA's distribution. It is calculated annually by HUD using data from the census, AHS and CPI samples, when available, combined with local random samples. The FMR can be interpreted as the price for a rental unit of about average quality. ${ }^{19}$ Data on rents and other characteristics of rental units also come from the 1985 and 1995 national samples of the American Housing Survey. Finally, I obtain similar results using median rent data by metropolitan area from the census. Data on housing prices comes from the Freddie Mac/Fannie Mae (FM) repeated sales index and from reported median house values by MSA from the census. ${ }^{20}$

Data on the evolution of population and income at the MSA level are from the BEA Regional Information System (REIS). Unemployment rates at the metro level are obtained from the Bureau of Labor Statistics (BLS). Other data on the characteristics of the central cities are obtained from the County and City Data Book (1998). The stock of immigrants in 1980 come from the 1980 Census, County Data. I obtain the longitudinal data on housing permits from the Census "Construction Reports: Series C40."

Several data sources are used for the countries of origin of the foreign born. My main data sources are the "World Bank Indicators" and the IMF "Financial Indicators" databases. Data about military conflicts and governance failures are from the "Internal Wars and Failures of

\footnotetext{
18 The 2002 fiscal year, for example, spans from October 2001 to the end of September 2002.

${ }^{19}$ From 1996 on, HUD changed the definition of FMR to the rent for a unit in the $40^{\text {th }}$ percentile. HUD provides data for both the $45^{\text {th }}$ and the $40^{\text {th }}$ percentile in 1995 . I use the ratio of rents in both percentiles and the evolution of rents in the $45^{\text {th }}$ percentile from 1995 to extrapolate the evolution of rents in the $40^{\text {th }}$ percentile.

${ }^{20}$ In table 6 I combine the Freddie Mac data from repeated sales data from the Office of Federal Housing Oversight (OFHEO) in order to improve the coverage of the data.
} 
Governance 1954-1996" database, from the Center for International Development and Conflict Management at the University of Maryland.

The main unit of observation in most of the empirical work is the MSA-year. In Table 1, I provide some descriptive statistics for the MSAs in 1990. I define the yearly immigration impact as the number of new immigrants divided by the current population. The average city (means are population-weighted) received a yearly inflow of immigrants equivalent to $0.3 \%$ of its initial population. But the variance of this impact is considerable. The maximum impact in 1990 was $1.4 \%$ of the population, in Miami. Miami was also the city with the greatest share of foreign-born population in 1980 (35.55\%). Overall, about 8\% of the urban population was foreign-born in 1980.

The rest of the variables summarized are used as controls in most regressions. Amenities such as crime and temperature (the log of heating degree days), and the initial share of population with a bachelor's degree are important determinants of population growth (Glaeser, Kolko and Saiz, 2001, Glaeser and Shapiro, 2001; Rappaport, 1999). The log of central city area may capture supply factors related to zoning. Changes in local income and the local unemployment are also important determinants of rent and housing values (Jud, Benjamin and Sirmans, 1996). I include these variables with one lag in the basic specifications. All regressions control for year dummies, which capture national trends in inflation and other economic variables. In some of the regressions I also control for state fixed effects and the growth of the native population in the city.

Appendix Table A.2 is helpful in describing the correlates of the variable of interest. In the regression in panel $\mathrm{B}$, the total number of immigrants (1983-98) over population (1983) is the dependent variable. Again, the most important predictor of immigration is the stock of foreignborn in 1980. Immigration partially correlates with central city area, the percentage of the population with a bachelor's degree (positive), and with income growth and cold weather (negative).

\section{Methodology and Results}

\subsection{Least squares results}

In section 3 I established that, ceteris paribus, the immigration impact should be one of the determinants of rents and housing price growth. The empirical model that I posit takes the form: 


$$
\Delta \ln \left(r_{i t}\right)=\beta \cdot \frac{i m m i_{i t-1}}{p o p_{i t-1}}+\alpha \cdot X_{i}+\mu \cdot \Delta Z_{i t-1}+\phi_{t}+\varepsilon_{i t}
$$

The dependent variable is the annual change in the log of rents. ${ }^{21}$ Taking differences in the rents series increases the noise to signal ratio of the dependent variable but gets rid of cityspecific characteristics that account for rent levels. The main independent variable is annual inflow of legal immigrants (INS data) over population. $\beta$ has an intuitive interpretation here as the percentage change in rents corresponding to an annual inflow of immigrants equal to $1 \%$ of the city's population. As rents do not adjust instantaneously to changes in fundamentals (Genesove, 1999) I use lagged values of the dynamic independent variables. To decide on the lags in the dynamic explanatory variables I used the Akaike Information Criterion (AIC) and concluded that the specification with one lag was the "most likely." ${ }^{22}$

Levin and Lin (1992) tests on the data for rents, and prices reveal stationarity in the first differences. Thus spurious regression seems not to be problem in this specification, though note that if there is a longer term cointegrating relationship between rent levels and the size of foreign born population we may be underestimating the parameter of interest. ${ }^{23}$

Table 5 shows the results of the first differences specification. I present the OLS regressions with standard errors clustered by MSA. I also show regressions using maximum likelihood estimation of a model with $\operatorname{ARMA}(2,2)$ perturbations to address the possible existence

\footnotetext{
${ }^{21}$ I have estimated more general dynamic panel data models that use the current rent as dependent variable and one lag in rents as independent variable, besides the other variables in the model. I implemented the GMM procedure in Arellano and Bond (1991), but specification tests failed to confirm the validity of the model, since second order autocorrelation in the residuals was detected. The qualitative results are similar for rents, but the specification for prices is extremely sensitive to changes in the set of explanatory variables.

${ }^{22}$ The AIC is commonly used to settle on the lag specification of time-series models: the specification that minimizes AIC is usually chosen. I posit specifications similar to the one in Table 2, column 1, but with different lags for the dynamic variables (immigration, income and employment rate). Notice that the rest of variables do not change over time, and cannot be lagged. I restrict the sample to the number of observations of the specification with the greater number of lags (four), to enable the comparison of the models. The model with one lag in the dynamic dependent variables minimizes the Akaike information criterion. See Appendix Table A.3.

${ }^{23}$ This problem suggest using long differences to estimate such long-run relationship, which I will implement later.
} 
autocorrelation and moving averages. ${ }^{24}$ There is evidence of both autocorrelation and moving averages in the data. It is not surprising that unobserved factors affecting rents and housing prices display such time persistence at the MSA level. In this setup, OLS is a consistent but relatively inefficient estimator. The results (columns 1,2,4 and 5) show that immigration is a significant explanatory variable for changes in rents. Results are fairly robust across specifications and suggest that rents increase by about $1 \%$ with an immigration impact equal to $1 \%$ of the city's population. The estimate for prices are bigger and more imprecise. The price series displays greater volatility than the rents series, and most of the estimates of the price regressions have bigger standard errors.

The shortcoming in the estimates is that a major part of the variance in immigration inflows is between cities. Omitted variables that are differentially present in cities with high immigration inflows, and that might account the growth in rents in these cities (such as amenities whose valuation increases over time), are a potential threat to my interpretation of the results. A first solution to the potential problem is to control for omitted variables that are common to all MSAs in a state. These may be, for instance, geographical advantages, regional demographics and state-specific shocks that are not captured in the income and employment variables. Columns (3) and (6) show the first-differences regressions including state fixed-effects. This is equivalent to allowing state specific trends in the evolution of rents and prices. The results do not change much; differences in immigration between cities within a state seem to have an equally strong impact on rents.

To eliminate the possibility of city-specific trends that are correlated with immigration levels I make use of the model in second differences:

$$
\Delta^{2} \ln \left(r_{i t}\right)=\beta \cdot \Delta \frac{i m m i_{i t-1}}{p o p_{i t-1}}+\mu \cdot \Delta^{2} Z_{i t-1}+\phi_{t}{ }^{\prime}+\xi_{i t}
$$

The model is identified through changes in the general level of new immigration into a city. Even if immigrants are generally attracted to a city because of factors that also drive the trend in rent growth, year to year changes in immigration inflows should be relatively independent of those factors. Do rents accelerate when immigration accelerates? The answer to this question is also in Table 2: yes. At the same time that

\footnotetext{
${ }^{24}$ The covariance of the difference of the perturbation terms is different from zero for two consecutive observations: $\operatorname{cov}\left(\varepsilon_{t}-\varepsilon t_{t-1}, \varepsilon_{t-1}-\varepsilon_{t-2}\right)=-E\left(\varepsilon_{t-1}^{2}\right)$. By construction, the new perturbation is a moving average of the contemporaneous and past perturbation.
} 
the specification in second differences prevents the omitted variables problem, the results capture the impact of unexpected immigration. Differences in the immigration inflows by year can be interpreted as "surprises." As the model predicted, unexpected changes in immigration cause higher rent growth. The estimate is large compared to those of the other methods: an increase in immigration equal to $1 \%$ of the population induces a rent hike of $3.75 \%$. Changes in prices are not significant in this specification.

\subsection{Instrumental Variables Estimates}

In this section I develop an instrumental variables' strategy to deal with the endogeneity problem. The evidence I obtain will be generalizable to regular (expected) immigration flows, and will not be dependent on major immigration "shocks."

I make use of two kinds of instrumental variables. The first instrumental variable approach focuses on year-to-year changes in immigration inflows. There are good reasons to believe that the overall number of legal immigrants in the United States stems from political and administrative decisions. ${ }^{25}$ I make use of this variation to construct a "shift-share" prediction of the inflows by city and year. Total immigration levels in the US are translated into expected immigration by city. I use the cities of destination of immigrants in 1983, the first year for which I have data on the location of legal immigrants, and the formula:

$$
\widehat{i m m i_{k, t}}=\frac{\phi_{k, 1983}}{\left(1-\phi_{k, 1983}\right)} \cdot\left(\overline{i m m i_{U S, t}} \cdot\left[1-\phi_{k, t}\right]\right)
$$

$\widehat{\mathrm{immi}_{k, t}}$ is the predicted number of new immigrants in city $k$ and year $t, \widehat{\mathrm{immi}_{U S, t}}$ is the total number of new immigrants in the United States in year $t$, and $\phi_{k, t}$ is the share of immigrants who move into city $k$ in year $t$. This prediction is independent of city and time specific shocks. Two basic identification assumptions are made. First, I assume that immigrant inflows in 1983 are not driven by omitted variables that will affect rents in the future. In other

\footnotetext{
${ }^{25}$ Successive "Immigration Acts" have established a cap to the total number of immigrants in the United States. The number of applicants has always exceeded the total cap. In 1994, for example, the U.S State Department had 3.6 million people registered in a "waiting list" for family reunification visas: the supply of immigrants is virtually infinite and the total number of immigrants admitted depend on administrative and legal decisions. In recent years, administrative backlogs have been an important determinant of the year-toyear level of immigrants into the United States. The INS estimated that legal immigration during the fiscal years $95-98$ period would have been 450,000-550,000 higher in the absence of the backlog.
} 
words, immigrants in 1983 did not predict the future evolution of housing rents and prices better than the participants in the local market. ${ }^{26}$ The second identifying assumption is the exogeneity of annual changes in the national immigration inflows to the economic conditions of immigrant cities.

The second IV approach relaxes this second assumption and consists in estimating annual immigration inflows by country and year. To do so, I use variables that are exogenous to changes in city-specific amenities. Once I have predicted immigration inflows by country and year I calculate the share of immigration by country into each MSA in 1983. I apply this share to predict the number of immigrants from each country into that city for the period 19841998. Finally, I consolidate these flows to obtain the total predicted immigration by city-year. This instrument takes the form:

$$
\overline{\overline{\mathrm{immi}_{k, t}}}=\sum_{i=1}^{M} \phi_{i, k, 1983} \cdot \overline{\overline{\mathrm{immi}_{i, U S, t}}}
$$

$\overline{\overline{i m m i_{k, t}}}$ is the predicted number of new immigrants in city $k$ at time $t, \phi_{i, k, 1983}$ is the share of immigrants from country $i$ who settled in city $k$ in 1983, and $\overline{\overline{i m m i} i_{i, U S, t}}$ is the predicted number of new immigrants from country $i$ and time $t$ in the United States. $\mathrm{M}$ is the total number of countries that sent immigrants to the U.S.

Appendix Table A.4 presents the results of a panel random effects model for the prediction of the number of immigrants by country. The dependent variable is the logarithm of immigrants from each country in a given year. The explanatory variables include lagged values of several of the sending countries' characteristics: the log of income per capita, log of population, log of the real exchange rate, dummies for the presence of miltary conflicts, collapse of state institution and transition out of communism, and the log of the number of immigrants from that country in 1979 (the first year for which the data is available). Income per capita is negatively related to the number of immigrants sent to the Unites States. The log of a country's population is also a significant determinant of the number of immigrants from that country. Real exchange rates have been shown to be an important determinant for Mexican

\footnotetext{
${ }^{26}$ Prices capitalize the discounted value of future rents and I find similar or bigger impacts of immigration on housing prices throughout the paper. Therefore, if one believed in the ability of immigrants in 1983 to pick the future "winner" cities (1984-1997) based on the available information, one has to explain why local participants in the housing market did not capitalize on the available information ex ante.
} 
immigration (Hanson and Spilimbergo, 1999). I measure the exchange rate as the unit of foreign "gadgets" that one can buy by selling a "gadget" produced in the U.S, priced at U.S prices and given the current exchange rate and prices in the sending country. Since this magnitude does not have a cross-sectional interpretation I use the exchange rate in 1979 as a benchmark. Results suggest that the greater the real purchasing power of the dollar in a country, the greater the expected immigration from that country. Military conflicts, collapse of state institutions and transition out of a communist regime are also positive determinants of emigration to the United States. The variable with the biggest explanatory power is the level of immigration by country in 1979. Overall levels of immigration by country are persistent. Information, history and American foreign policy, ethnic networks and permanent differences in the policies of sending countries may be important determinants of the country-specific levels of emigration to the United States.

The prediction of immigrants by country and year does not use the estimated random effects. The estimated country effects maybe correlated with factors that made it attractive to immigrate into the cities where immigrants of that nationality clustered during the 1984-98 period. The random effects estimate of immigration will thus be a linear combination of only the exogenous variables in Table A.4.

Once I have obtained the predictions by country, I apply the share of immigrants from that country that decided to settle in each city in 1983. From this I obtain predictions of the number of immigrants by nationality and metropolitan area. Adding these inflows by MSA, I obtain a prediction of immigrants per MSA and year.

Table A.5 portrays the first stage of the 2SLS estimation. In the first two the dependent variable here is the annual inflow of immigrants into a city, and the main explanatory variable is the predicted inflow of immigrants. Both the instrument based on the national level shiftshare (column 1) and the instrument based on sending country characteristics (column 2) work very well. F-test values for the instruments are around 300. In fact, most of the variation in these inflows is between cities, and changes in the annual levels of immigration and the characteristics of sending countries account for a lesser part of the variance in the instruments. Thus, I can predict general immigration flows by city during the 1984-1997 period well by using the destinations of immigrants in 1983.

Table 3 presents the basic results using instrumental variables. The results are similar than those in the OLS specification. In columns (1) and (2) I use the shift-share of the total number 
of immigrants admitted in the United States as an instrument. Columns (3) and (4) present the results with the instruments derived from predicting immigration by country. The results suggest estimates of around 1 for rents and 2 for housing prices.

\subsection{Long differences}

This section assesses the robustness of the estimates from the dynamic model. I use long differences in rents and prices and the cumulative number of INS-reported immigrants as the main dependent and explanatory variables. The specification attempts to answer an important policy question: what is the impact of immigration in the long run? If the impact of immigration is nonlinear, or the impact of immigration on rents takes a long adjustment period (i.e. immigration and rents are cointegrated), ${ }^{27}$ the estimates from our previous specifications may be quantitatively far from the actual long run effect. An additional advantage of the specification using "long" changes in rents and cumulative immigration is that they rely less in the reported timing of immigration, and are thus less sensitive to attenuation bias or potential non-classical measurement error in the yearly inflows.

Table 4 presents the results for rents and prices respectively. The left-hand-side variable is the change in the log of rents (prices) from 1984 to 1998. The main right-hand-side variables is the "potential supply" of immigrants over initial population (i.e. the total cumulative number of immigrants who reported settling in the city during the period 1983-1997 over population in 1983). ${ }^{28}$ Since most cities experience population growth, using the initial population in the

${ }^{27}$ Cointegration tests in this context are not extremely informative. The time dimension is very short (13 periods). Furthermore, the null hypothesis of cointegration usually involves cointegration of all of the MSA series: rejecting that hypothesis does not imply that some or even most of the series are cointegrated.

28 There are three arguments on why such "potential supply" is the treatment of interest. First, immigrants are no less concentrated in locations with major immigrant populations after 20 years residing in the United States (Ferrie, 1996b). This suggests a strong "stickiness" of immigration to the initial "ports of entry." Indeed, in footnote 29 I provide evidence between the one-to-one relationship between cumulative number of immigrants and change in population. Second, one may be interested in the "intention to treat" impact of immigration. Even if some of the immigrants leave the areas of initial settlement, it is important to know how the housing market responded for each immigrant that arrived in a city, in order to derive policy implications and forecasts, with the immigration data available. Third, and more importantly, "potential immigration" is the actual potentially exogenous treatment variable of theoretical interest. Internal migration of immigrants will be caused by changes in the conditions of the cities where the immigrants settle. These changes are endogenous to initial immigration inflows. We know that the local wage effects of immigration are small. Thus, a substantial part of an eventual out-migration of the foreign-born from 
denominator of this variable yields conservative (low) estimates of the parameter of interest. I also control for the changes in the log of income per capita during that period, and the rest variables that describe the initial conditions: unemployment, weather, crime, central city area, and percent with bachelor's degree in 1980.

The results are very robust across all specifications and suggest impacts on rents and prices of 0.8-1.6\% for an immigration inflow that amounts to $1 \%$ of the initial population. In general, point estimates for housing prices are higher, but I cannot reject that they are equivalent to those for rents. Columns 2, 3, 5, and 6 use the cumulative prediction from the origin countries' random effects estimation as an instrumental variable. In columns 3 and 6 I include the change in population other than immigrants (change in total population minus the estimated number of legal immigrants $)^{29}$ over initial population as an additional explanatory variable. The correlation between this variable and changes in rents and prices is not significant. Natives seem to be attracted to areas with relatively slow rent growth. However, as we will see latter, measurement error in the intercensal estimates of metropolitan population (1983 and 1997) is probably biasing down the association between population growth and changes in rents.

\subsection{Quality}

Another issue is the quality of the housing units in the HUD sample. The Freddie Mac (FM) measure of prices is based on a repeated sales index. The same units are tracked in time, and changes in quality must be small. The Fair Market Rent measure does not have this property. If the quality of housing increased systematically in "immigrant cities," maybe because growing cities tend to have housing units of newer vintages, my estimates could just be reflecting the effect of quality on rents. Conversely, immigration could actually be associated

\footnotetext{
"immigrant cities" might be attributed to local changes in housing costs. It is clear that people who have left a city because of the high housing costs are still part of the demand of housing in that city (if the price was low enough they would have bought housing services in the city). To clarify this point, imagine a city with a completely inelastic housing supply. Assume that everyone consumes the same quantity of housing services. In this setup, any immigration inflow will be associated with a population outflow of the same magnitude. Still, the greater the number of immigrants the greater the demand for housing in the city and the higher the rents: the number of net migrants to the city would be the wrong variable to use.

${ }^{28}$ Results do not change much if I include the lagged independent variable in a simple fixed effects model (unreported regression available on request).

${ }^{29}$ Running the regressions in table 4 with the relative change in population as dependent variable yields a coefficient of 0.70 on the immigration impact (standard error 0.277): I cannot reject that each cumulative potential immigrant predicts one new MSA inhabitant.
} 
with lower qualities, and the previous results would then be biased downward. I address this issue using microdata from the 1985 and 1995 samples of the American Housing Survey. ${ }^{30}$ The AHS provides several quality indicators that I will use as controls. An additional advantage of using the AHS is to check on the robustness of my previous findings on alternative data sources. In Table 5, the log of reported rent for each unit in both years is the left-hand-side variable. The interaction of the population impact of the cumulative number of INS-reported immigrants in the MSA (1984-1994) and a 1995 dummy captures the impact of recent immigration on the change in rents between 1985 and 1995. Other explanatory variables are change in income and the interaction between city characteristics and the 1995 dummy. MSA fixed effects model explicitly the covariance between observations in the same MSA. ${ }^{31}$ The quantitative results are remarkably similar to previous specifications $(0.8 \%$ extra rent growth for $1 \%$ impact), despite the fact that the time frame is different (10 years from 1985 to 1995), and the fact that the AHS tracks a much smaller number of metropolitan areas (only 141). Areas where immigrants settled tended to experience higher rent growth. The introduction of quality indicators (column 2) does not change the coefficient of interest.

\subsection{The foreign-born, rents and prices: using the decennial censuses.}

The INS provides data about illegal immigrant apprehensions and estimates of the net flows of illegal immigrants in several issues of the "Statistical Yearbook of the Immigration and Naturalization Service." Unfortunately, the estimates of the illegal net inflows are not disaggregated at the metropolitan area level. Moreover, the estimates of illegal immigration are imprecise and do not change much from year to year. A shortcoming of the data that I have used so far is that it does not include figures for illegal immigrants. We need to interpret the results so far as the treatment effect of legal immigration on rents and housing prices. This would not be problematic if illegal immigration was uncorrelated with legal immigration inflows. Unfortunately, this is an unlikely assumption. Nevertheless, there are reasons to believe that the exclusion of illegal immigrants may not affect the primary qualitative conclusions so far. Firstly, the estimated figures for net illegal immigration during the period correspond very well with the figures of emigration of legal residents. According to the Census Bureau (INS, 1999) about 260,000 foreign-born residents emigrated annually from the United States in the

\footnotetext{
${ }^{30}$ I restrict the sample to private metropolitan rental units for which the rent is reported.

31 As most units appear in both samples, I further cluster standard errors by unit.
} 
90s. The estimated number of annual illegal aliens entering the country was 281,000 for 1988-92 and 275,000 for 1992-1996 (INS, 1999). The effects of illegal immigration and emigration of the foreign-born may cancel each other to some extent. Secondly, it is unlikely that the correlation between legal and illegal inflows is equal to one.

In any case, a way to approach the issue of the foreign born persons who are not legal immigrants is by using census data counts at the MSA level. The census counts most foreignborn residents, irrespective of their immigrant status. ${ }^{32}$ The other advantage of using the census over the INS data is that it is free of measurement error in the reporting of the locations where the foreign born person decides to settle. The main disadvantage of the census is its periodicity. I will only be able to consider the "long" changes in rents and prices between the census years for which I have complete data (1970, 1980, 1990, and 2000). The other disadvantage of the census is that we do not obtain the MSA in which the immigrant first settled. Actual residence in an MSA may be endogenous to the rent level in the city. Theoretically, with a very inelastic housing supply, new immigration could have an impact on rents even if the net migration of the foreign born into the city is small. Using instrumental variables techniques may help us deal with that problem.

Table 6 presents the results from a regression where the decadal change in the census-reported $\log$ of the median rent or house value in the MSA are the main dependent variables. The change in the number of the foreign-born between two census years over population in the initial year is the main explanatory variable. As a data check for the quality of the selfreported data, and in order to account for some of the changes in unobserved quality, I also present the results with the repeated sales index. The data is a panel of 283 MSAs with complete data and 3 decades of growth in the foreign-born population. I use similar controls as in the previous regressions. ${ }^{33}$ OLS results (columns 1, 4 and 9) are remarkably consistent with the previous specifications. The parameter of interest is robust to the use of very different data sources.

\footnotetext{
32 There may be some concerns about the undercount of illegal immigrants in specific areas, but we can hardly improve on the census counts.

33 The MSA definition here is the 1999 county-based one (see data Appendix). I have data for murder rates (and not homogeneous data on serious crimes) by MSA only in 1980, 1990 and 2000, so I use contemporaneous murder rates on the right-hand-side (excluding crime does not change the coefficient of interest in any of the tables). There are a good deal of missing observations for the unemployment rate in 1970 so I use lagged employment rates (total employment over population).
} 
Columns 3, 6 and 10 introduce MSA fixed effects. The fixed effects should control for the impact of city-specific amenities (or changes in the valuation of amenities) that were associated with rent growth during the period. ${ }^{34}$ The identification there comes from quantitative changes in immigration within a city, rather than on the cross-sectional variation in the share of immigrants. Clearly, rent and house price growth in a city accelerated in the decades with bigger immigration inflows. The parameter estimates are bigger than with the OLS specification, albeit the parameters are more imprecisely estimated. The fact that rent and price growth accelerates when immigration inflows accelerate is consistent with a causal interpretation of the results.

In columns 3, 4, 7, 8, 11, and 12 I use an IV strategy in order to deal with the fact that changes in the location of the foreign-born are driven by housing costs and may be correlated with other relevant omitted variables. I predict the MSA change in the foreign-born according to the formula:

$$
\Delta \text { foreign }_{i t}=\Delta \text { foreign }_{U S, t} \times \frac{\text { foreign }_{i t-1}}{\text { foreign }_{U S, t-1}}
$$

Where foreign $_{i t}$ is the number of foreign-born people in city $i$ at time $t$, and foreign $_{U S, t}$ the number of foreign born in the US at time $t$. This basically amounts to multiply the initial level of the foreign born by the national growth rate in the number of foreign born persons, and thus is in the tradition of using initial immigration levels to predict subsequent inflows (Altonji an Card, 1991). I then divide by initial population to generate a prediction for the expected immigration impact in each city. The results suggest a somewhat lower elasticity of about 0.5 for rents and prices. ${ }^{35}$ When we control for other population growth, however, the estimates increase and suggest an elasticity of 0.8 . The change is explained by the fact that the partial correlation between changes in native population and the initial share of the foreign born is negative. The census measure of the change in the native population yields a strong positive impact of population growth on rents and prices. However, and consistent with the

\footnotetext{
34 Note that adding fixed effects to a model in differences will increase the noise-to-signal rate in the dependent variable. In this case, however, I have decennial changes in rents and prices, which are bound to be much less noisy than annual changes.

${ }^{35}$ Unfortunately I cannot combine the IV and fixed effects approach. The shares of the foreign born by city do not change much in each decade and the city and year fixed effects capture all of the variance in the instrument. The instrument is not significant in the first stage with MSA fixed effects and the F-statistic for the excluded instrument is only 0.80 .
} 
idea that native migration is more endogenous to local changes in the cost of living, this association is about 2-3 times weaker than the association between immigration and rent growth. ${ }^{36}$

\subsection{The distribution of the estimates}

At this point, I have presented a good deal of estimators that yield a very consistent picture: immigration pushes up rents and prices in the cities of destination. While point estimates on the impact on rents are all surprisingly close, more uncertainty surrounds the point estimates for housing values. This was to be expected, since housing values' series typically display greater volatility than rents. But if we are willing to accept a common data generating process for the impact on rents and prices, as the model suggested, ${ }^{37}$ figure 1 is useful. Figure 1 shows a kernel density estimate of the 32 parameters in tables 2-6. It is quite apparent that the mode of the estimates is around 1. I think that it is thus fair to conclude that an exogenous immigration impact that amounts to $1 \%$ of the initial population in a metropolitan area pushes up average rents and prices by around $1 \%$.

\section{Conclusions}

This paper shows that there is a local economic impact of immigration in American cities. Immigration pushes up the demand for housing in the destination areas. Rents increase in the short run and housing prices gradually catch up. The association between immigration and rents appears to be causal. Acceleration or deceleration in the immigrant's inflows within a city is associated with acceleration or decelerations in the evolution of rents.

Instruments based on the characteristics of sending countries, the immigration level by country of origin in 1979 and the geographical distribution of immigrants by country in 1983, and instruments based on the year-to-year changes in national immigration levels and 1983 patterns of settlement, all yield similar result. Areas where one would expect immigrants to

\footnotetext{
${ }^{36}$ I have conducted two further robustness checks. First it is interesting to note that the results do not change much if we exclude Los Angeles, San Francisco and New York MSA, which have been salient areas of rent growth in recent periods. Second, it also interesting to point out that the strong correlation between immigration and rent/value growth is still very strong if we omitted the control variables (except for the time dummies, which capture national levels of inflation and other general components of rent growth). The coefficients are around 0.5-0.6.

37 Ongoing and future research by this author will analyze the impact of immigration in the different segments of the local housing markets.
} 
settle experienced higher rent and housing price evolution, regardless of the economic shocks and different fates experienced by the cities during the 15-year period between 1984 and 1998 . The results also hold for census data for the 1970-2000 period. And they are very robust to the use of different data sources (Freddie Mac price index, HUD Fair Market Rents, American Housing Survey rents, Census median house prices and rents, INS legal immigrant data vs. census counts of the foreign-born) and time periods.

An immigration inflow that amounts to $1 \%$ of the initial metropolitan area population is associated with, roughly, a $1 \%$ increase in rents and housing values. One should be cautious about the interpretation of these results. Renters will be less attracted by immigrant cities with relatively higher housing costs, but homeowners experience a capital gain. Immigration does seem to have a local distributive impact.

In any case, the results need to be taken into account to understand how immigration inflows are spatially arbitraged away. To illustrate this point, it is useful to benchmark the results in this paper to the results in the wage literature. The population-weighted average share of the foreign-born in the US (metropolitan areas in the 2000 census) is $12 \%$. To increase this share by $1 \%$ the average city needs an immigration inflow equal to $1.15 \%$ of the initial population. Using the modal estimate in the paper this could increase rents by $1.15 \%$. Arguably, as the labor literature seems to point out to, a $1 \%$ increase in the share of immigrants depresses wages by $0.03 \%$. The typical renter-occupied household spends about $1 / 4$ of their income in rental payments. This amounts to a loss of purchasing power of about $0.28 \%$ if they decide to stay and don't alter their housing consumption, which is an order of magnitude bigger than the effect through the labor market! Workers in sectors and occupations different than those in which immigrants tend to cluster are participants in the housing market. Clearly, housing rents and prices must be important explanatory variables in further research about the interplay between immigrants, labor markets, and the mobility of natives. 


\section{References}

[1] Altonji, J.G. and D.Card (1991). "The Effects of Immigration on the Labor Market Outcomes of Less-Skilled Natives," in Immigration, Trade, and the Labor Market, ed. John M. Abowd and Richard B. Freeman (Chicago: University of Chicago Press, 1991), pp. 201-34.

[2] Angrist, J. and A.Krueger (2000). "Empirical Strategies in Labor Economics." In O. Ashenfelter and R. Layard, Eds., "The Handbook of Labor Economics, vol.III". North Holland.

[3] Arellano, M. and S.Bond (1991). "Some Tests of Specification for Panel Data: Monte Carlo Evidence and an Application to Employment Equations." Review of Economic Studies 58, pp.277-297.

[4] Borjas, G. (1994a). "The Economics of Immigration." Journal of Economic Literature, vol.32, No.4; pp.1667-1717.

[5] Borjas, G. (1994b). "The Economic Benefits of Immigration." Journal of Economic Perspectives, vol.9, 3-22.

[6] Borjas, G. (2000). "Foreign-born Teaching Assistants and the Academic performance of Undergraduates. American Economic Review, 2000, vol. 90, issue 2, pp. 355-359

[7] Borjas, G., Freeman, R.B. and L.F.Katz (1992). "On the Labor Market Effects of Immigration and Trade." In George J. Borjas and Richard B. Freeman, ed. "Immigration and the Work Force: Economic Consequences for the United States and Source Areas." Chicago: The University of Chicago Press.

[8] Borjas, G. and L.Hilton (1996). "Immigration and the Welfare State: Immigrant Participation in Means-Tested Entitlement Programs." The Quarterly Journal of Economics. Vol.111(2), p.575-604.

[9] Burnley, I., Murphy, P. and R.Fagan (1997). "Immigration and Australian Cities." Sidney: The Federation Press Pty Ltd.

[10] Callis, R.(1997). "Moving to America- Moving to Homeownership." Current Housing Reports, H121/97-2: United States Census Bureau.

[11] Capozza, D., Hendershott, P., Mack, C., and C. Mayer (2002). "The Determinants of House Price Dynamics." NBER Working Paper Series, No.W9262.

[12] Card, D. (1990). "The Impact of the Mariel Boatlift on the Miami Labor Market." Industrial \&3 Labor Relations Review, vol. 43 (2), p.245-57. January 1990. 
[13] Card, D. E. and Krueger, A.B.(1995). "Myth and Measurement: The New Economics of the Minimum Wage." Princeton: Princeton University Press.

[14] Case, K.E. and R.J. Shiller (1989). "The Efficiency of the Market for Single Family Homes." American Economic Review, vol.79, No.1, pp.125-137.

[15] Edin, P.A, Fredirksson, P. and O.Aslund (2003). "Ethnic Enclaves and the Economic Success of Immigrants - Evidence from a Natural Experiment." Quarterly Journal of Economics, Februrary 2003, pp.329-357.

[16] Fairlie, R.W. and Meyer, B.D. (2000). "The Effect of Immigration on Native SelfEmployment." NBER Working Paper Series, No.W7561.

[17] Ferrie, J.P. (1996a). "The Impact of Immigration on Natives in the Antebellum U.S., 1850-60." Northwestern University Center for Urban Affairs and Policy Research, Working Paper No. WP-96-14 (March 1996).

[18] Ferrie, J.P. (1996b). "Immigrants and Natives: Comparative Economic Performance in the U.S., 1850-60 and 196580." NBER Working Paper No. H0093.

[19] Filer, R.K. (1992). "Immigrant Arrivals and the Migratory Patterns of Native Workers", in Borjas,G.J. and R.B. Freeman, eds. "Immigration and the Workforce." Chicago: The University of Chicago Press.

[20] Friedberg, R.M. and J.Hunt (1995). "The Impact of Immigrants on Host Country Wages, Employment and Growth." Journal of Economic Perspectives 9, pp.23-44.

[21] Friedman, S., Rosenbaum, E. \& M. Schill (1998). "The Housing Conditions of Immigrants in New York City." Fannie Mae Working paper. Fannie Mae Foundation.

[22] Gang, I. And F.L. Rivera-Batiz (1999). "Immigrants and Unemployment in the European Community." Institute for the Study of Labor (IZA), Discussion Paper No.70, November 1999.

[23] Genesove, D. (1999). "The Nominal Rigidity of Apartment Rents." NBER Working Paper Series, No.W7137.

[24] Glaeser, E., Kolko, J. and A.Saiz (2000). "Consumer City." Journal of Economic Geography, 1, pp.27-50.

[25] Glaeser, E. and Shapiro, J. (2001). "Is There a New Urbanism? The Growth of U.S. Cities in the 1990s." NBER Working Paper Series, No.W8357.

[26] Goldin, C. (19944). "The Political Economy of Immigration Restriction in the United States, 1890 to 1921." In C.Goldin and G.D.Libecap, eds. "The Regulated 
Economy: A Historical Approach to Political Economy." Chicago: University of Chicago Press.

[27] Gross, D.M. (1999). "Three Million Foreigners, Three Million Unemployed? Immigration and the French Labor Market." Working Paper of the International Monetary Fund, WP/99/124.

[28] Hanson, G.H. and A.Spilimbergo (1999). "Illegal Immigration, Border Enforcement, and Relative Wages: Evidence from Apprehensions at the US-Mexico Border." American Economic Review, vol. 89, pp.1337-1357.

[29] Hoxby,C. (1998). "Do Immigrants Crowd Disadvantaged American Natives Out of Higher Education?" in Hamermesh, D.S and F.D. Dean "Help or Hindrance: The Economic Implications of Immigration for African Americans". New York: Russell Sage Foundation.

[30] Immigration and Naturalization Service (1999). "1999 Statistical Yearbook of the Immigration and Naturalization Service" U.S. Government Printing Office: Washington, D.C

[31] Joint Center for Housing Studies of Harvard University (2000). "The State of the Nation's Housing 2000." Cambridge: Harvard University.

[32] Joint Center for Housing Studies of Harvard University (2001). "The State of the Nation's Housing 2001." Cambridge: Harvard University.

[33] Jud, G.D., Benjamin, J.D. and G.S. Sirmans (1996). "What Do We Know about Apartments and Their Markets?" The Journal of Real State Research, vol.11, No.2, pp.243-257.

[34] Levin, A. and C.F.Lin (1992). "Unit Root Test in Panel Data: Asymptotic and Finite Sample Properties." Discussion Paper \#92-93, University of California at San Diego.

[35] Ley, D. and J.Tuchener (1999). "Immigration and Metropolitan House Prices in Canada." Research on Immigration and Integration in the Metropolis (Vancouver Center of Excellence): Working Paper \#99-09.

[36] Malpezzi, S. (1999). "A Simple Error Correction Model of Housing Prices." Journal of Housing Economics 8, pp.27-62.

[37] Meese, R. and N. Wallace (1997). "Dwelling Price Dynamics in Paris, France." Mimeo.

[38] Muller, Thomas, and Thomas J. Espenshade, The Fourth Wave: California's Newest Immigrants, Washington: The Urban Institute Press (1985). 
[39] Munshi, K. (2003). "Networks in the Modern Economy: Mexican Migrants in the U.S. Labor Market." The Quarterly Journal of Economics, May 2003, pp.549-599.

[40] Myers, D. (1999). "Upward Mobility in Space and Time: Lessons from Immigration." In J.W.Hughes and J.J.Seneca, eds. "America's Demographic Tapestry. Baseline for the Millenium." New Brunswick: Rutgers University Press.

[41] Myers, D. Baer, W.C and S.Y. Choi (1996). "The Changing Problem of Overcrowded Housing." Journal of the American Planning Association, v.62, pp.6684.

[42] Myers, D. and S.W.Lee (1996). "Immigration Cohorts and Residential Overcrowding in Southern California." Demography, vol.33, No.1, pp.51-65.

[43] Myers, D. and Park, J. (1999). "The Role of Occupational Achievement in Homeownership Attainment by Immigrants and Native Borns in Five Metropolitan Areas." Journal of Housing Research, vol.10, No.1, pp.61-93.

[44] National Research Council (1997). "The New Americans: Economic, Demographic and Fiscal Effects of Immigration." Washington: National Academy Press.

[45] Passel, J.S. and W.Zimmermann (2001). "Are Immigrants Leaving California? Settlement Patterns of Immigrants in the Late 1990s." Washington: The Urban Institute.

[46] Portes, A. and R.G.Rumbaut (1996). "Immigrant America: A Portrait." University of California Press: Berkeley.

[47] Rappaport, J. (1999). "Local Growth Empirics." Harvard Center for International Development Working Paper No. 23

[48] Rumbaut, R.G. (1997). "Immigration to the United States Since World War II," in Hamamoto D.Y. and R.D.Torres, eds. "New American Destinies: A Reader in Contemporary Asian and Latino Immigration." Routledge: New York.

[49] Saiz, A. (2003). "Room in the Kitchen for the Melting Pot: Immigration and Rental Prices." The Review of Economics and Statistics. Forthcoming.

[50] Simon, J.L. (1999). "The Economic Consequences of Immigration." Ann Arbor: The University of Michigan Press.

[51] Thave, S.(1999). “ Les étrangers et leurs logements." INSEE Première n.689, December 1999.

[52] Zhou, M. (1998). "American Becoming: Contemporary Immigration and the Dynamics of Race and Ethnicity." Paper for the Conference on Racial Trends in the United States, National Research Council, Washington. 
TABLE 1

Descriptive Statistics (1990)

\begin{tabular}{|c|c|c|c|c|c|c|}
\hline \multirow[b]{2}{*}{ Variable } & \multicolumn{2}{|c|}{ Population Weighted } & \multicolumn{2}{|c|}{ Non-weighted } & \multirow[b]{2}{*}{ Min } & \multirow[b]{2}{*}{ Max } \\
\hline & Mean & Std. Dev. & Mean & Std. Dev. & & \\
\hline Rent & 562 & 130 & 490 & 107 & 321 & 930 \\
\hline New immigrants/population & 0.003 & 0.004 & 0.0015 & 0.002 & 0.000 & 0.016 \\
\hline Immigrant stock in 1980/ 1980 population & 0.076 & 0.066 & 0.045 & 0.046 & 0.005 & 0.356 \\
\hline Income per capita & 21003 & 3627 & 18487 & 3455 & 9335 & 31516 \\
\hline Unemployment rate & 5.411 & 1.681 & 5.763 & 2.275 & 2.100 & 22.300 \\
\hline Heating degree days & 4299 & 2106 & 4574 & 2221 & 199 & 10816 \\
\hline Central city area (square miles) & 134 & 155 & 70 & 135 & 3 & 1732 \\
\hline Serious crimes per person in 1985 & 0.089 & 0.032 & 0.077 & 0.034 & 0.000 & 0.384 \\
\hline Percentage with bachelor's degree in 1980 & 17.241 & 6.516 & 17.945 & 8.065 & 5.500 & 59.500 \\
\hline
\end{tabular}

Notes: Observations at the MSA, PMSA level. The number of MSA (with complete observations) is 296. 
TABLE 2

Immigrant Inflows and Annual Log Rent Changes

\begin{tabular}{|c|c|c|c|c|c|c|c|c|}
\hline & \multicolumn{3}{|c|}{$\Delta$ Log rent } & \multicolumn{3}{|c|}{$\Delta$ Log price } & \multirow{2}{*}{$\frac{\Delta^{2} \text { Log rent }}{(7)}$} & \multirow{2}{*}{$\frac{\Delta^{2} \text { Log price }}{(8)}$} \\
\hline & (1) & (2) & (3) & (4) & (5) & (6) & & \\
\hline New immigrants per population at $\mathrm{T}-1$ & $\begin{array}{c}1.148 \\
(0.378)^{\star * *}\end{array}$ & $\begin{array}{c}1.100 \\
(0.236)^{\star \star \star}\end{array}$ & $\begin{array}{c}0.842 \\
(.288)^{\star * *}\end{array}$ & $\begin{array}{c}1.912 \\
(0.403)^{\star * *}\end{array}$ & $\begin{array}{c}2.328 \\
(0.383)^{\star \star *}\end{array}$ & $\begin{array}{c}1.916 \\
(0.366)^{\star \star \star}\end{array}$ & $\begin{array}{c}3.759 \\
(1.681)^{\star *}\end{array}$ & $\begin{array}{c}-1.597 \\
(1.128)\end{array}$ \\
\hline$\Delta$ Log income at $\mathrm{T}-1$ ( $\Delta^{2}$ Log income $)$ & $\begin{array}{c}0.058 \\
(0.048)\end{array}$ & $\begin{array}{c}0.091 \\
(0.0370)^{\star *}\end{array}$ & $\begin{array}{c}0.070 \\
(0.043)\end{array}$ & $\begin{array}{c}0.668 \\
(0.098)^{\star * *}\end{array}$ & $\begin{array}{c}0.163 \\
(0.032)^{\star * *}\end{array}$ & $\begin{array}{c}0.155 \\
(0.032)^{\star \star *}\end{array}$ & $\begin{array}{c}0.104 \\
(0.058)^{*}\end{array}$ & $\begin{array}{c}0.092 \\
(0.036)^{\star *}\end{array}$ \\
\hline Unemployment rate at $\mathrm{T}-1$ ( $\Delta$ unemployment rate) & $\begin{array}{c}-0.142 \\
(0.027)^{\star * *}\end{array}$ & $\begin{array}{c}-0.106 \\
(0.027)^{* *}\end{array}$ & $\begin{array}{c}-0.102 \\
(-0.030)^{\star \star \star}\end{array}$ & $\begin{array}{c}-0.420 \\
(0.074)^{\star * *}\end{array}$ & $\begin{array}{c}-0.240 \\
(0.045)^{\star * *}\end{array}$ & $\begin{array}{c}-0.261 \\
(0.04047)^{\star \star *}\end{array}$ & $\begin{array}{l}-0.046 \\
(0.139)\end{array}$ & $\begin{array}{c}-0.488 \\
(0.097)^{\star * *}\end{array}$ \\
\hline Log heating degree days & $\begin{array}{c}0.00003 \\
(0.001)\end{array}$ & $\begin{array}{l}0.0004 \\
(0.001)\end{array}$ & $\begin{array}{c}0.004 \\
(0.002)^{*}\end{array}$ & $\begin{array}{c}0.006 \\
(0.001)^{\star * *}\end{array}$ & $\begin{array}{c}0.008 \\
(0.001)^{* * *}\end{array}$ & $\begin{array}{c}0.008 \\
(0.003)^{\star *}\end{array}$ & & \\
\hline Log central city area & $\begin{array}{c}-0.001 \\
(0.0006)^{*}\end{array}$ & $\begin{array}{c}-0.001 \\
(0.0006)^{\star}\end{array}$ & $\begin{array}{l}-0.0004 \\
(0.001)\end{array}$ & $\begin{array}{c}-0.004 \\
(0.0009)^{\star * *}\end{array}$ & $\begin{array}{c}-0.005 \\
(0.0008)^{\star * *}\end{array}$ & $\begin{array}{l}-0.0006 \\
0.001\end{array}$ & & \\
\hline Serious crimes per person, 1985 & $\begin{array}{c}0.041 \\
(0.011)^{\star * *}\end{array}$ & $\begin{array}{c}0.043 \\
(0.0147)^{\star *}\end{array}$ & $\begin{array}{c}0.025 \\
(0.017)\end{array}$ & $\begin{array}{c}0.056 \\
(0.027)^{\star *}\end{array}$ & $\begin{array}{c}0.016 \\
(0.027)\end{array}$ & $\begin{array}{c}0.020 \\
(0.022)\end{array}$ & & \\
\hline Share with bachelor's degree 1980 & $\begin{array}{c}0.004 \\
(0.007)\end{array}$ & $\begin{array}{c}0.069 \\
(0.076)\end{array}$ & $\begin{array}{c}0.012 \\
(0.008)\end{array}$ & $\begin{array}{l}-0.016 \\
(0.013)\end{array}$ & $\begin{array}{l}-0.013 \\
(0.013)\end{array}$ & $\begin{array}{c}0.003 \\
(0.000)\end{array}$ & & \\
\hline Year fixed effects & Yes & Yes & Yes & Yes & Yes & Yes & Yes & Yes \\
\hline $\operatorname{ARMA}(2,2)$ & No & Yes & Yes & No & Yes & Yes & No & No \\
\hline State fixed effects & No & No & Yes & No & No & Yes & No & No \\
\hline Observations & 4118 & 4118 & 4118 & 2170 & 2170 & 2170 & 4005 & 2211 \\
\hline R-squared & 0.19 & $\mathrm{ML}$ & $\mathrm{ML}$ & 0.22 & $\mathrm{ML}$ & $\mathrm{ML}$ & 0.10 & 0.11 \\
\hline
\end{tabular}

Standard errors (clustered by MSA) in parentheses. $\Delta$ indicates first difference, $\Delta^{2}$ second differences.

* significant at $10 \%$; ** significant at $5 \%$; *** significant at $1 \%$.

First differences for years 85 to 98: observations with all explanatory variables complete. Second differences for the 86-98 period: all observations with dynamic variables (immigration, income, unemployment) complete.

ML: Estimated using maximum likelihood. "Basic" disturbances are assumed to follow the normal distribution.

The table shows the results of a regression where the annual change in the logarithm of rents (prices) is the dependent variable and the number of new immigrants divided by population in the

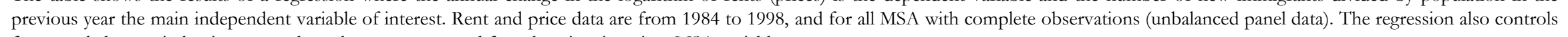
for annual changes in log income and employment rates, and for other time invariant MSA variables. 


\section{TABLE 3}

Immigrant Inflows and Annual Log Rent Changes: Instrumental Variables

\begin{tabular}{|c|c|c|c|c|}
\hline & \multicolumn{2}{|c|}{ US levels instrument } & \multicolumn{2}{|c|}{ Origin country instrument } \\
\hline & $\begin{array}{c}\Delta \text { Log rent } \\
\text { (1) }\end{array}$ & $\begin{array}{c}\Delta \text { Log price } \\
\text { (2) }\end{array}$ & $\begin{array}{c}\Delta \text { Log rent } \\
\text { (3) }\end{array}$ & $\begin{array}{c}\Delta \text { Log price } \\
\text { (4) }\end{array}$ \\
\hline New immigrants / population at T-1 & $\begin{array}{c}1.211 \\
(0.323)^{\star * \star}\end{array}$ & $\begin{array}{c}2.193 \\
(0.455)^{\star \star \star}\end{array}$ & $\begin{array}{c}1.150 \\
(0.323)^{\star \star \star}\end{array}$ & $\begin{array}{c}2.570 \\
(0.488)^{\star * *}\end{array}$ \\
\hline$\Delta$ Log income at $\mathrm{T}-1$ & $\begin{array}{c}0.058 \\
(0.048)\end{array}$ & $\begin{array}{c}0.668 \\
(0.098)^{\star * *}\end{array}$ & $\begin{array}{c}0.058 \\
(0.048)\end{array}$ & $\begin{array}{c}0.667 \\
(0.099)^{* * *}\end{array}$ \\
\hline Unemployment rate at $\mathrm{T}-1$ & $\begin{array}{c}-0.143 \\
(0.027)^{\star \star \star}\end{array}$ & $\begin{array}{c}-0.427 \\
(0.076)^{\star * *}\end{array}$ & $\begin{array}{c}-0.142 \\
(0.027)^{\star * \star}\end{array}$ & $\begin{array}{c}-0.437 \\
(0.076)^{\star * *}\end{array}$ \\
\hline Year fixed effects & Yes & Yes & Yes & Yes \\
\hline Other MSA variables in Table 2 & Yes & Yes & Yes & Yes \\
\hline Observations & 4118 & 2170 & 4118 & 2170 \\
\hline R-squared & 0.19 & 0.22 & 0.19 & 0.22 \\
\hline
\end{tabular}

Notes:

Standard errors clustered by MSA in parentheses. $\Delta$ indicates first difference.

* significant at $10 \%$; ** significant at $5 \%$; *** significant at $1 \%$.

First differences for years 85 to 97 : observations with all explanatory variables complete.

The table shows the results of a regression where the annual change in the logarithm of rents (prices) is the dependent variable and the number of new immigrants divided by population the previous year the main independent variable of interest. Rent and price data are from 1984 to 1998, and for all MSA with complete observations (unbalanced panel data). The regression also controls for annual changes in log income and unemployment rates, and for other time invariant MSA variables.

The "US levels instrument" uses the total number of immigrants in the US each year and the share of immigrants going to each MSA in 1983 to predict the number of immigrants by MSA and year. The "origin country instrument" is a prediction of MSA yearly immigration inflows based on "expected" immigration by country and the shares of immigrants of each nationality settling into each MSA in 1983. 
TABLE 4

Legal Immigrants and Rents: Long Differences

\begin{tabular}{|c|c|c|c|c|c|c|}
\hline & \multicolumn{3}{|c|}{$\Delta$ log rents $(84-98)$} & \multicolumn{3}{|c|}{$\Delta$ log prices $(84-98)$} \\
\hline & OLS & IV & IV & OLS & IV & IV \\
\hline & (1) & (2) & (3) & (4) & (5) & (6) \\
\hline Immigrants (1983-1997)/ 1983 population & $\begin{array}{c}\mathbf{0 . 8 6 8} \\
(0.204)^{\star * *}\end{array}$ & $\begin{array}{c}\mathbf{0 . 9 1 4} \\
(0.214)^{\star \star \star}\end{array}$ & $\begin{array}{c}\mathbf{0 . 9 3 5} \\
(0.214)^{\star * *}\end{array}$ & $\begin{array}{c}1.668 \\
(0.302)^{\star * *}\end{array}$ & $\begin{array}{c}1.581 \\
(0.312)^{\star * *}\end{array}$ & $\begin{array}{c}1.607 \\
(0.326)^{\star \star *}\end{array}$ \\
\hline$\Delta$ Log income 1983-1997 & $\begin{array}{c}0.496 \\
(0.081)^{\star * *}\end{array}$ & $\begin{array}{c}0.498 \\
(0.081)^{\star * *}\end{array}$ & $\begin{array}{c}0.498 \\
(0.081)^{\star * *}\end{array}$ & $\begin{array}{c}0.984 \\
(0.137)^{\star * *}\end{array}$ & $\begin{array}{c}0.979 \\
(0.137)^{\star * *}\end{array}$ & $\begin{array}{c}0.987 \\
(0.140)^{\star * *}\end{array}$ \\
\hline Unemployment rate 1984 & $\begin{array}{c}-0.587 \\
(0.233)^{* *}\end{array}$ & $\begin{array}{c}-0.590 \\
(0.233)^{* *}\end{array}$ & $\begin{array}{c}-0.564 \\
(0.234)^{\star *}\end{array}$ & $\begin{array}{c}1.964 \\
(0.458)^{\star * *}\end{array}$ & $\begin{array}{c}1.974 \\
(0.459)^{\star \star *}\end{array}$ & $\begin{array}{c}1.983 \\
(0.462)^{\star \star *}\end{array}$ \\
\hline Log heating degree days & $\begin{array}{c}0.014 \\
(0.010)\end{array}$ & $\begin{array}{c}0.015 \\
(0.010)\end{array}$ & $\begin{array}{c}0.019 \\
(0.010)^{*}\end{array}$ & $\begin{array}{c}0.089 \\
(0.017)^{\star * *}\end{array}$ & $\begin{array}{c}0.087 \\
(0.017)^{\star * *}\end{array}$ & $\begin{array}{c}0.089 \\
(0.018)^{\star * *}\end{array}$ \\
\hline Log central city area & $\begin{array}{l}-0.010 \\
(0.007)\end{array}$ & $\begin{array}{l}-0.010 \\
(0.007)\end{array}$ & $\begin{array}{l}-0.010 \\
(0.007)\end{array}$ & $\begin{array}{c}-0.054 \\
(0.009)^{\star * *}\end{array}$ & $\begin{array}{c}-0.054 \\
(0.009)^{\star * *}\end{array}$ & $\begin{array}{c}-0.054 \\
(0.009)^{\star * *}\end{array}$ \\
\hline Serious crimes per person, 1985 & $\begin{array}{c}0.591 \\
(0.195)^{\star * *}\end{array}$ & $\begin{array}{c}0.585 \\
(0.195)^{\star * *}\end{array}$ & $\begin{array}{c}0.541 \\
(0.199)^{\star \star *}\end{array}$ & $\begin{array}{c}0.175 \\
(0.270)\end{array}$ & $\begin{array}{c}0.179 \\
(0.270)\end{array}$ & $\begin{array}{c}0.176 \\
(0.271)\end{array}$ \\
\hline Share with bachelor's degree 1980 & $\begin{array}{c}0.110 \\
(0.081)\end{array}$ & $\begin{array}{c}0.108 \\
(0.081)\end{array}$ & $\begin{array}{c}0.081 \\
(0.084)\end{array}$ & $\begin{array}{c}0.220 \\
(0.134)\end{array}$ & $\begin{array}{c}0.225 \\
(0.134)^{*}\end{array}$ & $\begin{array}{c}0.214 \\
(0.141)\end{array}$ \\
\hline Change in native population (1983-1997) / 1983 population & & & $\begin{array}{c}0.052 \\
(0.043)\end{array}$ & & & $\begin{array}{c}0.017 \\
(0.067)\end{array}$ \\
\hline Constant & $\begin{array}{l}-0.043 \\
(0.114)\end{array}$ & $\begin{array}{l}-0.050 \\
(0.115)\end{array}$ & $\begin{array}{l}-0.088 \\
(0.119)\end{array}$ & $\begin{array}{c}-0.900 \\
(0.177)^{\star * *}\end{array}$ & $\begin{array}{c}-0.878 \\
(0.178)^{\star * *}\end{array}$ & $\begin{array}{c}-0.902 \\
(0.200)^{\star * *}\end{array}$ \\
\hline Observations & 288 & 288 & 288 & 153 & 153 & 153 \\
\hline R-squared & 0.24 & 0.24 & 0.25 & 0.54 & 0.54 & 0.54 \\
\hline
\end{tabular}

Notes:

Standard errors in parentheses.

* significant at $10 \%$; ** significant at $5 \%$; *** significant at $1 \%$.

The table shows the results of a regression where the long difference (change from 1984 to 1998) in the logarithm of rents (prices) is the dependent variable and the number of new immigrants during the period 1983-1997 divided by initial population (1983) is the main independent variable of interest. Rent and price data are from 1984 to 1998, and for all MSA with complete observations. The regression also controls for annual changes in log income and employment rates, and for other time invariant MSA variables.

The IV (instrumental variables) specifications use the "origin country" instrument. The "origin country instrument" is a prediction of MSA yearly immigration inflows based on "expected" immigration by country and the shares of immigrants of each nationality settling into each MSA in 1983. 


\section{TABLE 5}

Micro Data AHS: Rents and Qualities

\begin{tabular}{|c|c|c|}
\hline & \multicolumn{2}{|c|}{ Log rent at $T(T=1985,1995)$} \\
\hline & (1) & $(2)$ \\
\hline Immigration impact $\times 1995$ & $\begin{array}{c}\mathbf{0 . 7 9 6} \\
(0.180)^{* * *}\end{array}$ & $\begin{array}{c}\mathbf{0 . 8 7 2} \\
(0.177)^{\star \star *}\end{array}$ \\
\hline Log MSA income T-1 & $\begin{array}{c}0.765 \\
(0.131)^{\star * *}\end{array}$ & $\begin{array}{c}0.713 \\
(0.125)^{\star \star *}\end{array}$ \\
\hline Unemployment 1984 * 1995 & $\begin{array}{c}-0.050 \\
(0.381)\end{array}$ & $\begin{array}{c}-0.194 \\
(0.363)\end{array}$ \\
\hline Log heating degree days * 1995 & $\begin{array}{c}0.001 \\
(0.013)\end{array}$ & $\begin{array}{c}0.003 \\
(0.012)\end{array}$ \\
\hline Log central city area * 1995 & $\begin{array}{c}-0.014 \\
(0.007)^{\star}\end{array}$ & $\begin{array}{c}-0.017 \\
(0.007)^{\star *}\end{array}$ \\
\hline Crime 1985 * 1995 & $\begin{array}{c}-1.136 \\
(0.290)^{\star * *}\end{array}$ & $\begin{array}{c}-1.236 \\
(0.278)^{\star * *}\end{array}$ \\
\hline Share bachelors * 1995 & $\begin{array}{c}-0.398 \\
(0.149)^{* * *}\end{array}$ & $\begin{array}{c}-0.338 \\
(0.140)^{* *}\end{array}$ \\
\hline 1995 & $\begin{array}{c}0.262 \\
(0.119)^{\star *}\end{array}$ & $\begin{array}{c}0.312 \\
(0.115)^{\star * *}\end{array}$ \\
\hline Cracks in walls & & $\begin{array}{c}-0.060 \\
(0.013)^{\star * *}\end{array}$ \\
\hline Leaking ceiling & & $\begin{array}{l}-0.018 \\
(0.015)\end{array}$ \\
\hline Heat down on winter & & $\begin{array}{c}-0.011 \\
(0.020)\end{array}$ \\
\hline Fuses blew last 3 months & & $\begin{array}{c}0.028 \\
(0.010)^{* *}\end{array}$ \\
\hline Peels in paint & & $\begin{array}{c}-0.028 \\
(0.014)^{*}\end{array}$ \\
\hline Rats or mice & & $\begin{array}{c}-0.132 \\
(0.015)^{\star \star \star}\end{array}$ \\
\hline Number of units in building & & $\begin{array}{l}0.0004 \\
(0.0003)\end{array}$ \\
\hline Elevator present & & $\begin{array}{c}0.081 \\
(0.017)^{\star * *}\end{array}$ \\
\hline Number of bedrooms & & $\begin{array}{c}0.130 \\
(0.006)^{\star \star *}\end{array}$ \\
\hline Age of building & & $\begin{array}{c}-0.005 \\
(0.0001)^{\star * *}\end{array}$ \\
\hline MSA fixed Effects & Yes & Yes \\
\hline Year fixed effects & Yes & Yes \\
\hline Observations & 15692 & 15692 \\
\hline R-squared & 0.3 & 0.38 \\
\hline
\end{tabular}

Notes:

Standard errors clustered by unit in parentheses.

* significant at $10 \%$; ** significant at $5 \%$; *** significant at $1 \%$.

Immigration impact stands for the number of immigrants during the 1984-1994 period divided by 1984 population. The impact is instrumented by the prediction from the "origin countries" IV. 
TABLE 6

Census Data: 1970, 1980, 1990 and 2000

\begin{tabular}{|c|c|c|c|c|c|c|c|c|c|c|c|c|}
\hline & \multicolumn{4}{|c|}{$\Delta$ Log median Rent } & \multicolumn{4}{|c|}{$\Delta$ Log median home value } & \multicolumn{4}{|c|}{$\Delta$ Log repeated home sales index } \\
\hline & $\begin{array}{l}\text { OLS } \\
\text { (1) }\end{array}$ & $\begin{array}{l}F E \\
(2) \\
\end{array}$ & $\begin{array}{l}\text { IV } \\
(3) \\
\end{array}$ & $\begin{array}{l}\text { IV } \\
(4)\end{array}$ & $\begin{array}{l}\text { OLS } \\
(5)\end{array}$ & $\begin{array}{l}\mathrm{FE} \\
\mathbf{( 6 )} \\
\end{array}$ & $\begin{array}{l}\text { IV } \\
(7) \\
\end{array}$ & (8) & & $(10)$ & $(11)$ & $(12)$ \\
\hline New (10 year) immigrants per initial population & $\begin{array}{c}\mathbf{0 . 9 3 7} \\
(0.111)^{\star \star \star}\end{array}$ & $\begin{array}{c}1.938 \\
(0.357)^{\star \star \star}\end{array}$ & $\begin{array}{c}\mathbf{0 . 5 6 2} \\
(0.114)^{\star \star \star}\end{array}$ & $\begin{array}{c}\mathbf{0 . 7 7 1} \\
(0.128)^{\star \star \star}\end{array}$ & $\begin{array}{c}1.957 \\
(0.231)^{\star \star \star}\end{array}$ & $\begin{array}{c}2.673 \\
(0.727)^{\star \star \star}\end{array}$ & $\begin{array}{c}\mathbf{0 . 3 4 9} \\
(0.236)\end{array}$ & $\begin{array}{c}\mathbf{0 . 8 0 0} \\
(0.220)^{\star \star \star}\end{array}$ & $\begin{array}{c}1.815 \\
(0.307)^{\star \star \star}\end{array}$ & $\begin{array}{c}4.882 \\
(2.029)^{\star \star}\end{array}$ & $\begin{array}{c}\mathbf{0 . 5 7 8} \\
(0.403)\end{array}$ & $\begin{array}{c}\mathbf{0 . 8 1 3} \\
(0.391)^{\star \star}\end{array}$ \\
\hline$\Delta$ Log income & $\begin{array}{c}0.860 \\
(0.063)^{\star \star *}\end{array}$ & $\begin{array}{c}0.934 \\
(0.092)^{\star \star \star}\end{array}$ & $\begin{array}{c}0.839 \\
(0.063)^{\star \star \star}\end{array}$ & $\begin{array}{c}0.814 \\
(0.059)^{\star \star \star}\end{array}$ & $\begin{array}{c}1.461 \\
(0.112)^{\star \star \star}\end{array}$ & $\begin{array}{c}1.675 \\
(0.175)^{\star \star *}\end{array}$ & $\begin{array}{c}1.371 \\
(0.112)^{\star * *}\end{array}$ & $\begin{array}{c}1.316 \\
(0.103)^{\star \star \star}\end{array}$ & $\begin{array}{c}1.630 \\
(0.154)^{\star \star \star}\end{array}$ & $\begin{array}{c}1.531 \\
(0.514)^{\star \star \star}\end{array}$ & $\begin{array}{c}1.539 \\
(0.155)^{\star \star *}\end{array}$ & $\begin{array}{c}1.551 \\
(0.150)^{\star \star *}\end{array}$ \\
\hline Employment Rate at T-10 & $\begin{array}{l}-0.270 \\
(0.171)\end{array}$ & $\begin{array}{c}-0.903 \\
(0.410)^{\star *}\end{array}$ & $\begin{array}{l}-0.126 \\
(0.175)\end{array}$ & $\begin{array}{l}-0.257 \\
(0.161)\end{array}$ & $\begin{array}{c}0.076 \\
(0.321)\end{array}$ & $\begin{array}{c}-1.778 \\
(0.831)^{\star *}\end{array}$ & $\begin{array}{c}0.695 \\
(0.358)^{*}\end{array}$ & $\begin{array}{c}0.413 \\
(0.303)\end{array}$ & $\begin{array}{c}0.570 \\
(0.455)\end{array}$ & $\begin{array}{c}0.085 \\
(2.376)\end{array}$ & $\begin{array}{c}0.842 \\
(0.438)^{*}\end{array}$ & $\begin{array}{c}1.027 \\
(0.452)^{\star *}\end{array}$ \\
\hline Log heating degree days & $\begin{array}{l}-0.008 \\
(0.005)\end{array}$ & $\begin{array}{c}0.064 \\
(0.014)^{* \star *}\end{array}$ & $\begin{array}{c}-0.018 \\
(0.005)^{\star \star \star}\end{array}$ & $\begin{array}{c}0.011 \\
(0.007)\end{array}$ & $\begin{array}{c}0.034 \\
(0.007)^{\star \star *}\end{array}$ & $\begin{array}{c}0.069 \\
(0.028)^{\star *}\end{array}$ & $\begin{array}{l}-0.009 \\
-0.009\end{array}$ & $\begin{array}{c}0.053 \\
(0.011)^{\star * *}\end{array}$ & $\begin{array}{c}0.059 \\
(0.011)^{\star \star \star}\end{array}$ & $\begin{array}{c}0.051 \\
(0.055)\end{array}$ & $\begin{array}{c}0.027 \\
(0.014)^{*}\end{array}$ & $\begin{array}{c}0.055 \\
(0.014)^{\star \star *}\end{array}$ \\
\hline Log central city area & $\begin{array}{c}-0.008 \\
(0.002)^{\star \star \star}\end{array}$ & $\begin{array}{c}0.016 \\
(0.012)\end{array}$ & $\begin{array}{c}-0.007 \\
(0.002)^{\star \star \star}\end{array}$ & $\begin{array}{c}-0.009 \\
(0.002)^{\star \star \star}\end{array}$ & $\begin{array}{c}-0.011 \\
(0.004)^{\star *}\end{array}$ & $\begin{array}{c}0.100 \\
(0.022)^{\star \star *}\end{array}$ & $\begin{array}{c}-0.008 \\
(0.004)^{*}\end{array}$ & $\begin{array}{c}-0.013 \\
(0.004)^{\star \star \star}\end{array}$ & $\begin{array}{c}-0.032 \\
(0.006)^{\star \star \star}\end{array}$ & $\begin{array}{c}0.283 \\
(0.125)^{\star *}\end{array}$ & $\begin{array}{c}-0.029 \\
(0.006)^{\star \star *}\end{array}$ & $\begin{array}{c}-0.033 \\
(0.006)^{\star \star *}\end{array}$ \\
\hline Murders per 100,000 inhabitants & $\begin{array}{c}0.002 \\
(0.0007)^{\star \star *}\end{array}$ & $\begin{array}{c}0.003 \\
(0.002)\end{array}$ & $\begin{array}{c}0.002 \\
(0.0006)^{\star \star *}\end{array}$ & $\begin{array}{c}0.003 \\
(0.0008)^{\star * *}\end{array}$ & $\begin{array}{c}0.001 \\
(0.001)\end{array}$ & $\begin{array}{c}0.009 \\
(0.003)^{\star \star *}\end{array}$ & $\begin{array}{c}0.001 \\
(0.001)\end{array}$ & $\begin{array}{c}0.003 \\
(0.001)^{\star *}\end{array}$ & $\begin{array}{c}0.002 \\
(0.002)\end{array}$ & $\begin{array}{c}0.002 \\
(0.013)\end{array}$ & $\begin{array}{c}0.001 \\
(0.002)\end{array}$ & $\begin{array}{c}0.003 \\
(0.002)\end{array}$ \\
\hline Percentage with bachelor's degree at T-10 & $\begin{array}{c}-0.004 \\
(0.0005)^{\star * *}\end{array}$ & $\begin{array}{l}-0.006 \\
(0.004)\end{array}$ & $\begin{array}{c}-0.003 \\
(0.0006)^{\star * *}\end{array}$ & $\begin{array}{c}-0.004 \\
(0.0006)^{\star * *}\end{array}$ & $\begin{array}{c}-0.005 \\
(0.001)^{* * *}\end{array}$ & $\begin{array}{c}-0.045 \\
(0.007)^{* \star *}\end{array}$ & $\begin{array}{l}-0.001 \\
(0.001)\end{array}$ & $\begin{array}{c}-0.004 \\
(0.001)^{\star \star *}\end{array}$ & $\begin{array}{c}-0.004 \\
(0.001)^{\star \star \star}\end{array}$ & $\begin{array}{c}-0.077 \\
(0.034)^{\star *}\end{array}$ & $\begin{array}{l}-0.001 \\
(0.001)\end{array}$ & $\begin{array}{l}-0.002 \\
(0.001)\end{array}$ \\
\hline Change in native/population at T-1 & & & & $\begin{array}{c}0.212 \\
(0.039)^{\star \star \star}\end{array}$ & & & & $\begin{array}{c}0.458 \\
(0.065)^{\star \star \star}\end{array}$ & & & & $\begin{array}{c}0.294 \\
(0.102)^{\star * \star}\end{array}$ \\
\hline Decade fixed effects & yes & yes & yes & yes & yes & yes & yes & yes & yes & yes & yes & yes \\
\hline MSA fixed effects & no & yes & no & no & no & yes & no & no & no & yes & no & no \\
\hline MSA & 283 & 283 & 283 & 283 & 283 & 283 & 283 & 283 & $261^{\dagger}$ & $261^{\dagger}$ & $261^{\dagger}$ & $261^{\dagger}$ \\
\hline Observations & 849 & 849 & 849 & 849 & 849 & 849 & 849 & 849 & 414 & 414 & 414 & 414 \\
\hline R-squared & 0.88 & 0.9 & 0.88 & 0.89 & 0.79 & 0.84 & 0.78 & 0.81 & 0.38 & 0.67 & 0.34 & 0.37 \\
\hline
\end{tabular}

Robust standard errors in parentheses

* Unbalanced panel for 1990 and 2000 .
significant at $10 \%$; ** significant at $5 \%$; ** significant at $1 \%$

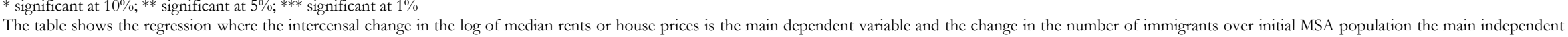

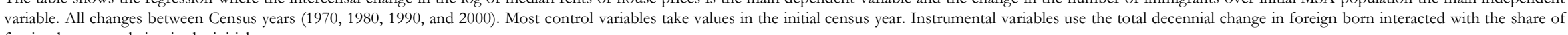
foreign-born population in the initial year. 
Figure 1. Kernel density of the paper's estimates

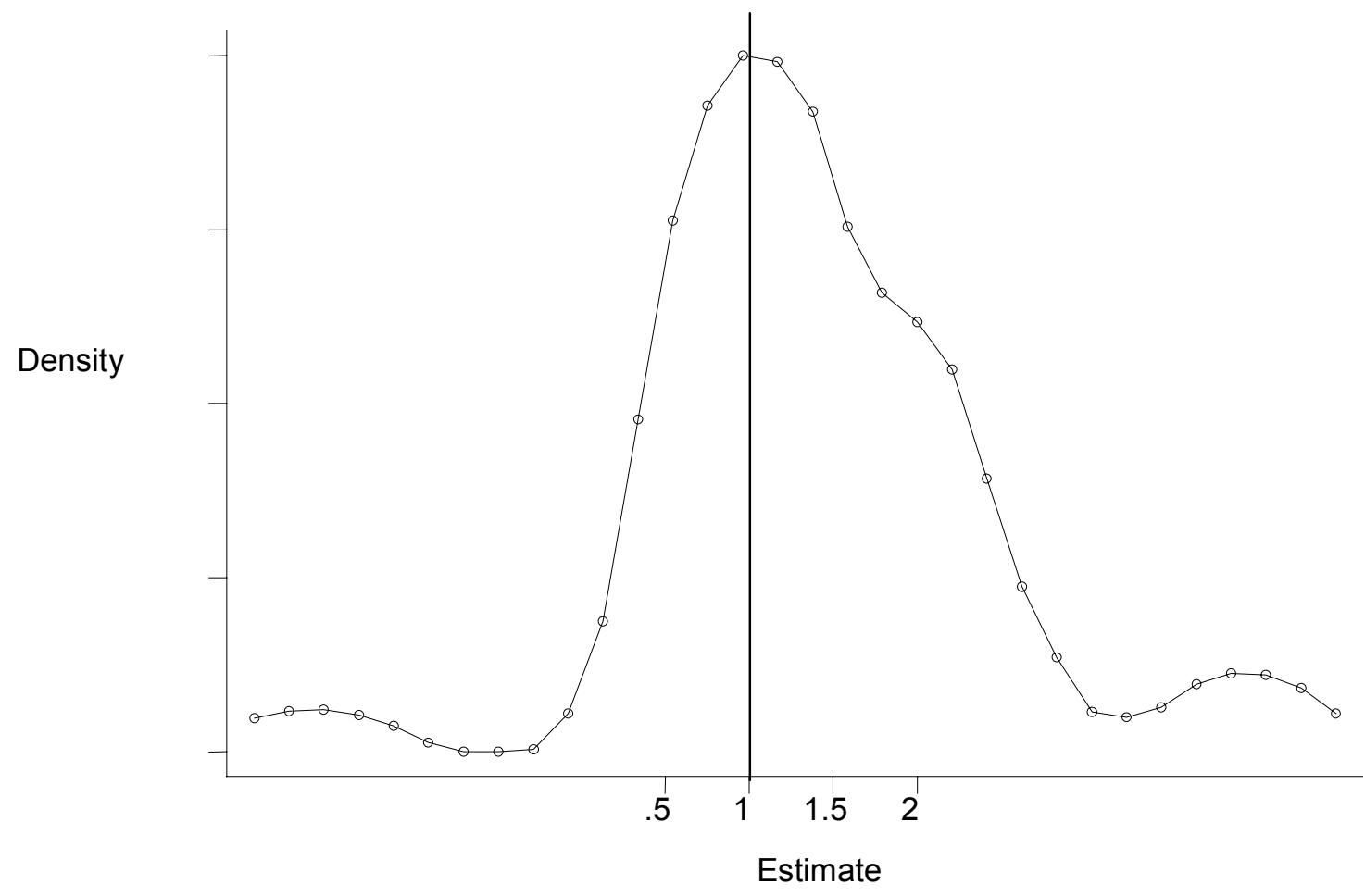




\section{Appendix TABLE A.1 \\ Major Immigrant Cities (1983-1997)}

\begin{tabular}{|c|c|c|c|}
\hline Rank MSA & Population 1983 & $\begin{array}{l}\text { Legal immigrants 1983- } \\
\qquad 1997\end{array}$ & Impact ${ }^{*}$ \\
\hline 1 New York & 8384789 & 1576355 & $18.80 \%$ \\
\hline 2 Los Angeles-Long Beach & 7890314 & 1057856 & $13.41 \%$ \\
\hline 3 Miami & 1725589 & 435697 & $25.25 \%$ \\
\hline 4 Chicago & 7259019 & 408727 & $5.63 \%$ \\
\hline 5 Washington & 3632843 & 338378 & $9.31 \%$ \\
\hline 6 San Francisco & 1531795 & 253691 & $16.56 \%$ \\
\hline 7 Anaheim-Santa Ana (Orange County) & 2072418 & 243263 & $11.74 \%$ \\
\hline 8 Houston & 3150230 & 215113 & $6.83 \%$ \\
\hline 9 San Jose & 1367215 & 206228 & $15.08 \%$ \\
\hline 10 Oakland & 1843567 & 186436 & $10.11 \%$ \\
\hline 11 Boston & 5359877 & 182568 & $3.41 \%$ \\
\hline 12 San Diego & 2003313 & 174730 & $8.72 \%$ \\
\hline 13 Newark & 1953448 & 163320 & $8.36 \%$ \\
\hline 14 Philadelphia & 4791248 & 146834 & $3.06 \%$ \\
\hline 15 Bergen-Passaic & 1298675 & 143482 & $11.05 \%$ \\
\hline 16 Nassau-Suffolk & 2621072 & 132523 & $5.06 \%$ \\
\hline 17 Dallas & 2249095 & 125081 & $5.56 \%$ \\
\hline 18 Seattle-Bellevue-Everett & 1712491 & 113649 & $6.64 \%$ \\
\hline 19 Jersey City & 566829 & 106735 & $18.83 \%$ \\
\hline 20 Detroit & 4229636 & 105756 & $2.50 \%$ \\
\hline $\begin{array}{c}10 \text { Biggest Immigrant Cities } \\
\% \text { Metropolitan US }\end{array}$ & $\begin{array}{c}38,857,779 \\
19.90 \%\end{array}$ & $\begin{array}{c}4,921,743 \\
53.07 \%\end{array}$ & $12.67 \%$ \\
\hline $\begin{array}{c}20 \text { Biggest Immigrant Cities } \\
\% \text { Metropolitan US }\end{array}$ & $\begin{array}{c}65,643,463 \\
33.61 \%\end{array}$ & $\begin{array}{c}6,316,422 \\
68.11 \%\end{array}$ & $9.62 \%$ \\
\hline
\end{tabular}

Notes: All magnitudes at the PMSA or MSA level

*(Immigrants /1983 Population), total immigrants obtained as the sum of legal immigrants in fiscal years 1983 through 1997. 


\section{Appendix TABLE A.2}

\section{Correlates of MSA Legal Immigration Inflows}

Panel A: Partial Correlations of Interest

New immigrants (1997-1993)/Population 1983

Other Population Growth (1983-1997)/Population 1983

Log Rents 1983

Foreign Born/Population (1980 Census)

Change in log income 1983-1997

Change in log employment level 1983-1997
Other Population

Growth (1983-

New immigrants

(1997-1993) /

1997) / Population

Population 1983

1983

\begin{tabular}{cc}
1 & 0.168 \\
0.168 & 1 \\
0.515 & 0.146 \\
$\mathbf{0 . 8 9 1}$ & 0.083 \\
-0.128 & 0.029 \\
0.086 & $\mathbf{0 . 8 5 3}$ \\
\hline
\end{tabular}

Panel B: Immigration Flows on Stocks and Control V ariables
Immigrants/Population 1980

Change in log incomes 83-97

Unemployment rate 1984

Log heating degree days

Log central city area

Serious crimes per person, 1985

Share with bachelor's degree 1980

Constant
New immigrants (1997-1993)/ Population 1983

$(0.019)^{\star * \star}$

$-0.022$

$(0.011)^{\star *}$

0.045

$(0.032)$

$-0.003$

$(0.001)^{\star}$

0.003

$(0.0009)^{\star * \star}$

0.036

(0.026)

0.048 $(0.0109)^{\star \star *}$

0.010

(0.015)

Note: Standard errors in parenthesis. 
Appendix TABLE A.3

Model Selection: Lags in Dynamic Variables

\begin{tabular}{|c|c|c|}
\hline & \multicolumn{2}{|c|}{ Akaike Information Criterion } \\
\hline & $\Delta$ Log Rent & $\Delta$ Log Price \\
\hline One Lag & -11410.21 & -6055.82 \\
\hline Two Lags & -11378.22 & -5944.02 \\
\hline Three Lags & -11357.50 & -5896.08 \\
\hline Four Lags & -11291.03 & -5885.40 \\
\hline
\end{tabular}




\section{Appendix TABLE A.4}

Accounting for Immigration

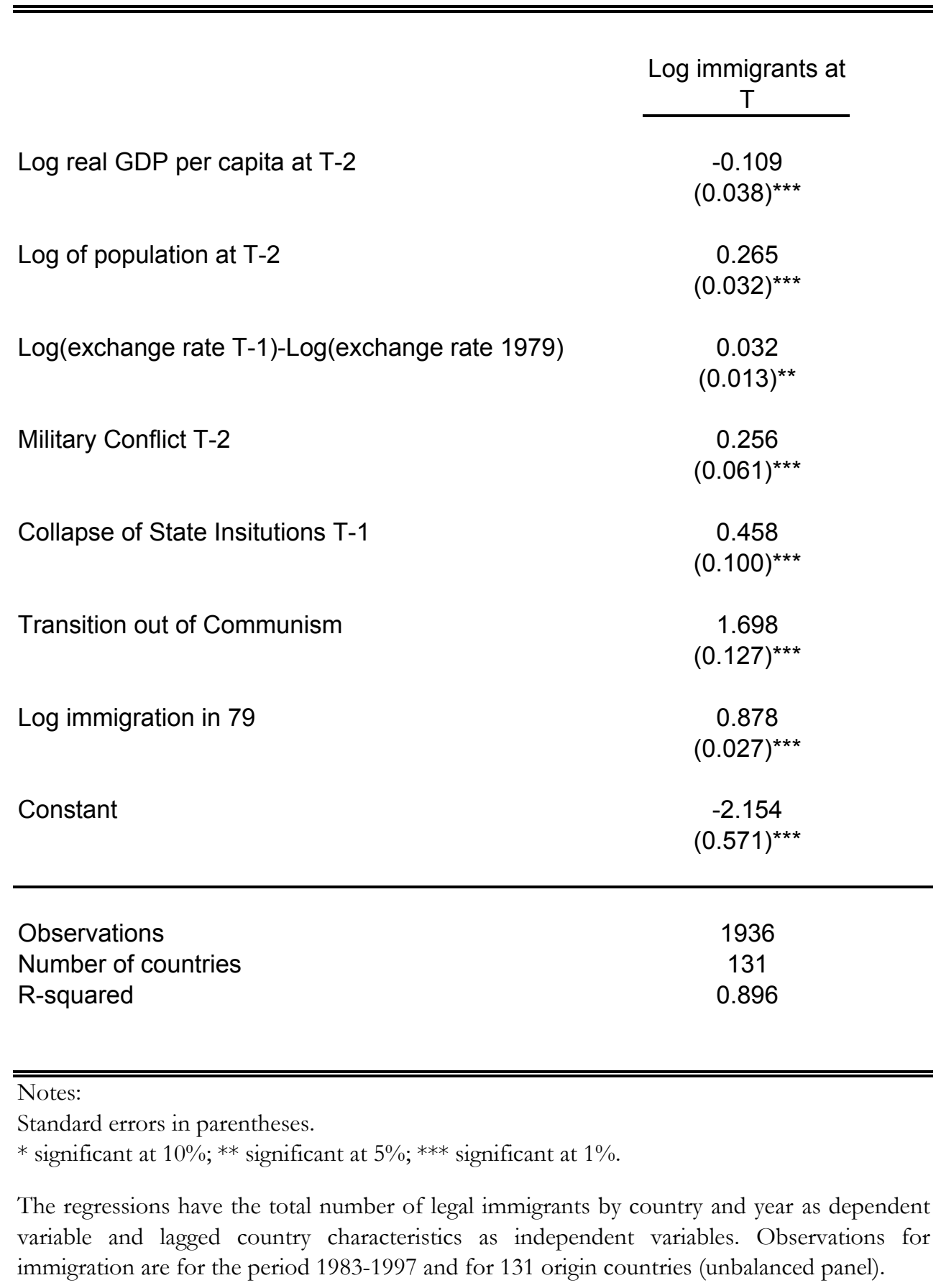




\title{
Appendix TABLE A.5
}

\author{
First Stage for Instruments
}

\begin{tabular}{|c|c|c|c|}
\hline & \multicolumn{3}{|c|}{ New Immigrants per Population } \\
\hline & \multicolumn{2}{|c|}{ Yearly Differences (INS) } & $\begin{array}{c}\text { Deccennial (census) } \\
\text { (3) }\end{array}$ \\
\hline Predicted impact (from national level shift-share) & $\begin{array}{c}0.954 \\
(0.057)^{\star \star *}\end{array}$ & & $\begin{array}{c}0.846 \\
(0.070)^{\star * *}\end{array}$ \\
\hline Predicted impact (from origin countries RE) & & $\begin{array}{c}0.847 \\
(0.045)^{\star * *}\end{array}$ & \\
\hline Other MSA variables in Table 5 & yes & yes & yes \\
\hline Year fixed effects & yes & yes & yes \\
\hline $\begin{array}{l}\text { Observations }(\mathrm{N} \times \mathrm{T}) \\
\text { R-squared }\end{array}$ & $\begin{array}{l}4118 \\
0.84\end{array}$ & $\begin{array}{l}4118 \\
0.87\end{array}$ & $\begin{array}{l}849 \\
0.62\end{array}$ \\
\hline F-test statistic for excluded instrument & 274.31 & 343.66 & 142.71 \\
\hline \multicolumn{4}{|l|}{$\begin{array}{l}\text { Notes: } \\
\text { Robust standard errors in parentheses } \\
* \text { significant at } 10 \% ; * * \text { significant at } 5 \% ; * * *\end{array}$} \\
\hline \multicolumn{4}{|c|}{$\begin{array}{l}\text { The table show the regressions of actual immigration inflows on the predictions (instrumental variables). The first two columns use } \\
\text { annual legal immigration inflows from the INS. The "national level shift-share" instrument (column 1) uses the share of } \\
\text { immigrants to each city in } 1983 \text { and the total number of immigrants in the US to predict immigration inflows by year and MSA } \\
\text { after } 1983 \text {. The "origin countries" instrument predicts immigration by nationality and year and uses the shares of immigrants by } \\
\text { nationality and MSA in } 1983 \text { to predict the total number of immigrants by MSA and year after 1983. The "national level shift- } \\
\text { share" regression in column } 3 \text { uses the total decennial national change in the number of the foreign born between Census' years } \\
\text { and the share of foreign-born in the previous census year as instrument for the change in the foreign-born by MSA and year. }\end{array}$} \\
\hline
\end{tabular}




\section{Data Appendix}

\begin{tabular}{|c|c|c|}
\hline Variable & Definition/notes & Table \\
\hline Rent & $\begin{array}{l}\text { HUD Fair Market Rent. These are obtained directly from HUD by } \\
\text { MSA. HUD reports rents at the } 45 \% \text { of the rent distribution. After } \\
\text { 1996, rents for the } 40^{\text {th }} \text { percentile are reported. In } 1995 \text { both the } 40^{\text {th }} \\
\text { and } 45^{\text {th }} \text { percentile are reported, and I use subsequent growth ratios } \\
\text { to extrapolate } 45^{\text {th }} \text { percentile rents from } 1996 \text { on. The fair market } \\
\text { rent that is applicable to a fiscal year (which starts in October) is } \\
\text { calculated and published during the previous fiscal year. Thus, the } \\
1997 \text { FMR was actually calculated and published in 1996. I use the } \\
\text { year of publication in the empirical specifications. }\end{array}$ & $\begin{array}{l}\text { T1, } 2 \text {, } 13, \\
\text { T4, } \\
\text { TA.2, }\end{array}$ \\
\hline Rent & $\begin{array}{l}\text { American Housing Survey } 1985-1995 \text {. Self-reported rent in renter } \\
\text { occupied metropolitan households. }\end{array}$ & T5 \\
\hline Rent & $\begin{array}{l}\text { Median MSA rent. HUD State of the Cities Data System (from } \\
\text { Census) }\end{array}$ & $\mathrm{T} 6$ \\
\hline House price & $\begin{array}{l}\text { Freddie Mac Repeated sale index. Complemented with data from } \\
\text { OFHEO (Table 6, } 1990 \text { and 2000). }\end{array}$ & $\begin{array}{l}\text { T1, T2, T3, } \\
\text { T4, T6, TA.3 }\end{array}$ \\
\hline Income & $\begin{array}{l}\text { Average MSA per capita income from the Bureau of Economic } \\
\text { Analysis (BEA) }\end{array}$ & $\begin{array}{l}\text { T1, T2, T3, } \\
\text { T4, T5, T6, } \\
\text { TA.2, TA.3 }\end{array}$ \\
\hline $\begin{array}{l}\text { Unemployment } \\
\text { Rate }\end{array}$ & At the MSA level. Bureau of Labor Statistics. & $\begin{array}{l}\text { T1, T2, T3, } \\
\text { T4, T5, TA.2, } \\
\text { TA.3 }\end{array}$ \\
\hline Employment Rate & $\begin{array}{l}\text { Total MSA employment from the Bureau of Economic Analysis } \\
\text { (BEA) divide by MSA population (BEA). }\end{array}$ & $\mathrm{T} 6$ \\
\hline Population & MSA Population (BEA) & $\begin{array}{l}\text { T1, } \mathrm{T} 2, \mathrm{~T} 3, \\
\text { T4, } 55, \text { T6, } \\
\text { T7, } \\
\text { TA.3 }\end{array}$ \\
\hline Immigrants & $\begin{array}{l}\text { Number of new legal immigrant admissions by MSA (from INS } \\
\text { "Immigrants Admitted"). Immigrants are matched to } 1990 \text { MSA } \\
\text { boundaries using the Census Mable Geocorrlation engines. } \\
\text { Immigrants in zip codes that are not identified by MABLE are } \\
\text { allocated to MSAs (non-MSA status) using the same proportions in } \\
\text { the rest of the sample. }\end{array}$ & $\begin{array}{l}\text { T1, T2, T3, } \\
\text { T4, T5, TA.1, } \\
\text { TA.2, TA.3 }\end{array}$ \\
\hline Immigrants & Head count of the foreign born at the MSA level. & $\mathrm{T} 1, \mathrm{~T} 6$ \\
\hline $\begin{array}{l}\text { Heating degree } \\
\text { days }\end{array}$ & $\begin{array}{l}\text { This is an indicator of cold weather. } 1988 \text { County and City Data } \\
\text { Books }\end{array}$ & $\begin{array}{l}\text { T1, } \mathrm{T} 2, \quad \mathrm{~T} 3, \\
\text { T4, T5, T6, } \\
\text { T7, } \\
\text { TA.3 }\end{array}$ \\
\hline
\end{tabular}




\begin{tabular}{|c|c|c|}
\hline Central City Area & $\begin{array}{l}\text { Area (square miles) of the major central city in the MSA.1988 } \\
\text { County and City Data Books. }\end{array}$ & $\begin{array}{l}\text { T1, T2, T3, } \\
\text { T4, T5, T6, } \\
\text { T7, } \\
\text { TA.3 }\end{array}$ \\
\hline $\begin{array}{lr}\text { Share } & \text { with } \\
\text { bachelors degree } \\
(1980)\end{array}$ & 1988 County and City Data Books & $\begin{array}{l}\text { T1, T2, T3, } \\
\text { T4, T5, T7, } \\
\text { TA.2, TA.3 }\end{array}$ \\
\hline $\begin{array}{lr}\text { Share } & \text { with } \\
\text { bachelors } & \text { degree } \\
\text { (decennial) } & \\
\end{array}$ & HUD State of the Cities Data System (from Census) & T6 \\
\hline $\begin{array}{l}\text { Serious Crimes per } \\
\text { Person } 1985\end{array}$ & 1988 County and City Data Books. & $\begin{array}{l}\text { T1, T2, T3, } \\
\text { T4, T5, T7, } \\
\text { TA.2, TA.3 }\end{array}$ \\
\hline $\begin{array}{l}\text { Murders per } \\
100.000 \text { persons } \\
\text { (decennial) }\end{array}$ & National Archive of Criminal Justice Data. & T6 \\
\hline $\begin{array}{l}\text { Real GDP per } \\
\text { capita }\end{array}$ & World Bank -World Development Indicators & TA.4 \\
\hline Population & World Bank -World Development Indicators & TA.4 \\
\hline Real exchange rate & $\begin{array}{l}\text { World Bank -World Development Indicators. It is calculated as the } \\
\text { (nominal GDP in domestic units/domestic GDP deflator) divided by } \\
\text { (nominal GDP in US \$/US GDP deflator) }\end{array}$ & TA.4 \\
\hline $\begin{array}{l}\text { Collapse of state } \\
\text { institutions }\end{array}$ & $\begin{array}{l}\text { Internal Wars and Failures of Governance 1954-1996" database, from } \\
\text { the Center for International Development and Conflict Management } \\
\text { at the University of Maryland. }\end{array}$ & TA.4 \\
\hline $\begin{array}{l}\text { Transition out of } \\
\text { communism }\end{array}$ & $\begin{array}{l}\text { Takes value } 1 \text { for communist countries after } 1989 \text { (except Cuba and } \\
\text { North Korea) }\end{array}$ & TA.4 \\
\hline Military conflict & $\begin{array}{l}\text { "Internal Wars and Failures of Governance 1954-1996" database, } \\
\text { from the Center for International Development and Conflict } \\
\text { Management at the University of Maryland }\end{array}$ & TA.4 \\
\hline
\end{tabular}

Other notes

1. Tables 1-5 use the 1990 MSA definitions. Data from BEA use 1999 MSAS/NECMA (county based) definitions, so I use initial population in 1980 and the growth rates of the closest NECMA-defined MSA (as reported by BEA) to estimate population by year by MSA (1990 defined). To assign income per capita to the New England MSAs I match the MSA to the NECMA with greater overlap using the census Mable geocorrelation engine.

2. Merging immigrant inflows with origin country data: Some of the countries in the INS files disappeared (merged or split). The World Bank data is reported for currently existing countries. I assign the individuals from these countries to a major "anchor" country as follows: 


\begin{tabular}{|l|l|}
\hline Anchor country (World Bank Data) & INS country \\
\hline Germany & East Germany \\
\hline Micronesia, Fed. Sts. & West Germany \\
& Northern Mariana Islands \\
& Marshal Islands \\
& Palau \\
& Micronesia \\
\hline New Zealand & New Zealand \\
& Cook Islands \\
\hline Russian Federation & Niue \\
\hline & USSR \\
& Moldova \\
& Russia \\
& Tajikstan \\
& Turkmenistan \\
& Ukraine \\
& Uzbekistan \\
& Armenia \\
& Azerbaijan \\
& Belarus \\
& Georgia \\
& Kazahkstan \\
& Kyrgyzstan \\
\hline Czech Republic & Czechoslovakia \\
& Czech Republic \\
\hline Ethiopia & Slovakia \\
\hline Yemen, Rep. of & Ethiopia \\
& Eritrea \\
\hline Spain & Yemen (Aden) \\
& Yemen (Saana) \\
& Yemen \\
\hline & Spain \\
& Gibraltar \\
\hline & Australia \\
& Christmas Island \\
& Cocos Islands \\
\hline & Yugoslavia \\
& Bosnia-Herzegovina \\
& Croatia \\
& Slovenia \\
& Macedonia \\
\hline & \\
\hline & \\
&
\end{tabular}

3. Incomplete country data: a number of countries have missing data. In those cases (in order to make a prediction of immigrants by year from those countries) I estimate a random effects model with immigration from that country in 1979 as the sole explanatory (without the estimated random effects). 